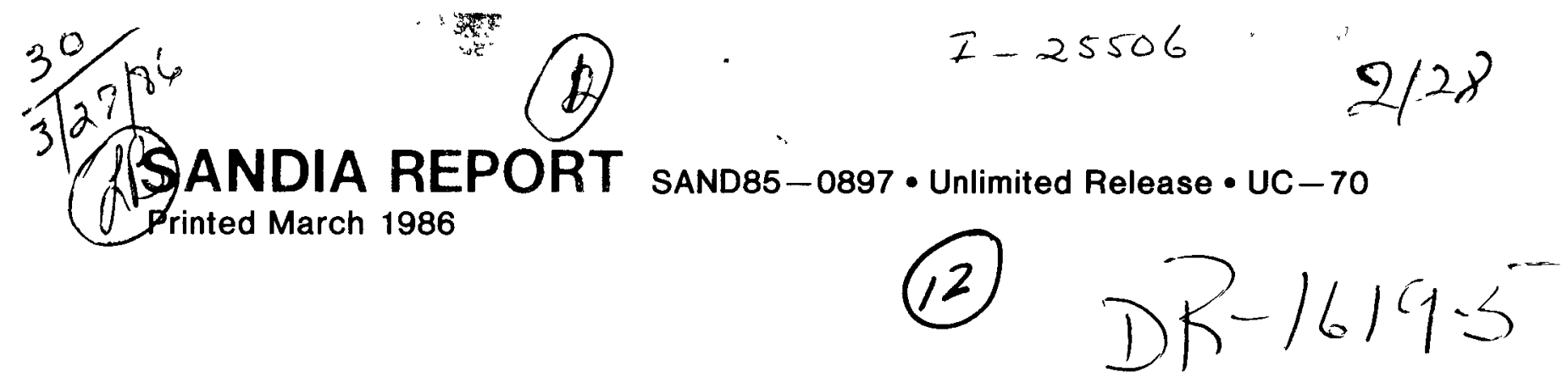

\title{
Chemistry of Brines in Salt from the Waste Isolation Pilot Plant (WIPP), Southeastern New Mexico: A Preliminary Investigation
}

Carol L. Stein, James L. KrumhansI

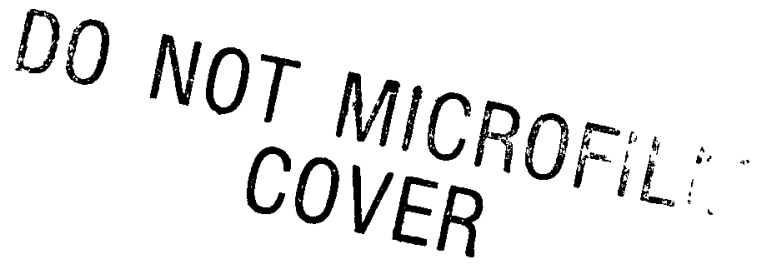

Prepared by

Sandia National Laboratories

Albuquerque, New Mexico 87185 and Livermore, California 94550

for the United States Department of Energy

under Contract DE-AC04-76DP00789 
Issued by Sandia National Laboratories, operated for the United States Department of Energy by Sandia Corporation

NOTICE: This report was prepared as an account of work sponsored by an agency of the United States Government Neither the United States Govern ment nor any agency thereof, nor any of their employees, nor any of their contractors, subcontractors, or their employees, makes any warranty, ex press or implied, or assumes any legal liability or responsibility for the accuracy, completeness, or usefulness of any information, apparatus, product, or process disclosed, or represents that its use would not infringe privately owned rights Reference herein to any specific commercial product, process, or service by trade name, trademark, manufacturer, or otherwise, does not necessarily constitute or imply its endorsement, recommendation, or favoring by the United States Government, any agency thereof or any of in do not necessarily state or reflect those of the United States Government, any agency thereof or any of their contractors or subcontractors

Printed in the United States of America Arallable from

National Techniral Information Service

US Department of Commerce

5285 Port Royal Road

Springfield, VA 22161

NTIS price codes

Printed copy A03

Microfiche copy A01

\section{DO NOT MICROFILM
THIS PAGE}




\section{DISCLAIMER}

This report was prepared as an account of work sponsored by an agency of the United States Government. Neither the United States Government nor any agency Thereof, nor any of their employees, makes any warranty, express or implied, or assumes any legal liability or responsibility for the accuracy, completeness, or usefulness of any information, apparatus, product, or process disclosed, or represents that its use would not infringe privately owned rights. Reference herein to any specific commercial product, process, or service by trade name, trademark, manufacturer, or otherwise does not necessarily constitute or imply its endorsement, recommendation, or favoring by the United States Government or any agency thereof. The views and opinions of authors expressed herein do not necessarily state or reflect those of the United States Government or any agency thereof. 


\section{DISCLAIMER}

Portions of this document may be illegible in electronic image products. Images are produced from the best available original document. 


\title{
Chemistry of Brines in Salt from the Waste Isolation Pilot Plant (WIPP), Southeastern New Mexico: A Preliminary Investigation
}

\author{
Carol L. Stein \\ Earth Sciences Division \\ James L. Krumhansl \\ Geochemistry Division \\ Sandia National Laboratories \\ Albuquerque, NM 87185
}

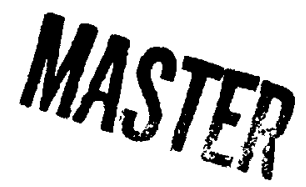

\begin{abstract}
The Waste Isolation Pilot Plant (WIPP) is a US Department of Energy-sponsored facility for the eventual disposal of defense-related transuranic nuclear waste, located in the Delaware Basin near Carlsbad, New Mexico. We present here analyses of macro- and microscopic (intracrystalline) brines observed within the WIPP facility and in the surrounding halite, with interpretations regarding the origin and history of these fluids and their potential effect(s) on long-term waste storage.

During excavation, several large ( $\sim 10 \mu \mathrm{m}$ to several millimeters) fluid inclusions were recovered from an area of highly recrystallized halite in a thick salt bed at the repository horizon (2150 ft below ground level). Two populations of inclusions were distinguished on the basis of major element content, using analyses for $\mathrm{Mg}, \mathrm{Ca}, \mathrm{K}, \mathrm{Na}, \mathrm{Cl}, \mathrm{Br}$, and $\mathrm{SO}_{4}$. We propose that the inclusion compositions arise from the alteration of calcium sulfate to polyhalite and calcium carbonate to magnesite, respectively. Overall, the inclusion compositions suggest a significant departure from a simple seawater evaporation model.

In addition, 52 samples of brine "weeps" were collected from walls of recently excavated drifts at the same stratigraphic horizon from which the fluid inclusion samples are assumed to have been taken. Analyses of these fluids show that they differ substantially in composition from the inclusion fluids (mainly by depletion of magnesium relative to potassium) and cannot be explained by mixing of the fluid inclusion populations. Since weeps are associated with argillaceous or anhydritic halite, these fluids may have originated by dewatering of clays and/or gypsum. Their compositions may have also been modified by selective uptake of $\mathrm{Mg}$ during clay diagenesis and by the formation of authigenic magnesite and magnesium silicates.
\end{abstract}

Finally, holes in the facility floor that filled with brine were sampled but with no stratigraphic control; therefore it is not possible to interpret the compositions of these brines with any accuracy, except insofar as they resemble the weep compositions but with greater variation in both $\mathrm{K} / \mathrm{Mg}$ 
and $\mathrm{Na} / \mathrm{Cl}$ ratios. However, the $\mathrm{Ca}$ and $\mathrm{SO}_{4}$ values for the floor holes are relatively close to the gypsum saturation curve, suggesting that brines filling floor holes have been modified by the presence of gypsum or anhydrite, possibly even originating in one or more of the laterally continuous anhydrite units referred to in the WIPP literature as marker beds.

In conclusion, the wide compositional variety of fluids found in the WIPP workings suggests that (1) an interconnected hydrologic system which could effectively transport radionuclides away from the repository does not exist; (2) brine migration studies and experiments must consider the mobility of intergranular fluids as well as those in inclusions; and (3) near- and far-field radionuclide migration testing programs need to consider a wide range of brine compositions rather than a few reference brines. 


\section{Acknowledgments}

We would like to thank all of the WIPP site personnel who made the sampling for this work possible. The field support provided by $\mathbf{M}$. Balderrama in particular is hereby acknowledged. D. Huskisson and W. Sorenson (SNL Div. 1822) provided the SEM/ EDAX and TEM work, respectively. The discussions held with H. D. Holland, B. Lazar, and W. R. Holser (Harvard Univ.) and E. Roedder (USGS-Reston) have been especially beneficial. Paul Knauth (Arizona State University) graciously supplied isotopic data; we are grateful for his generosity and for his willingness to share his ideas. The manuscript was much improved by the careful review given by A. R. Lappin (SNL Div. 6331). Finally, we thank D. F. McTigue (SNL Div. 1511) for his helpful comments and his assistance with the production of the final draft.

\section{DISCLAIMER}

\footnotetext{
This report was prepared as an account of work spong

Government. Neither the United States Government nor any an agency of the United States bility for the accuracy, completenessess or implied, or assumes any thereof, nor any of their process disclosed, or represents that its usefulness of any information, liability or responsimanufacture any specific commercial use would not infringe privat, apparatus, product, or mendation, or or otherwise does not necessarily process, or service by trade namights. Referand opinions of favoring by the United States Gonstitute or imply its endorseme, trademark, United States Governmentex express herein do not necent or any agency thereofent, recomvernment or any agency thereof.
necessarily state or reflect those views
} 


\section{Contents}

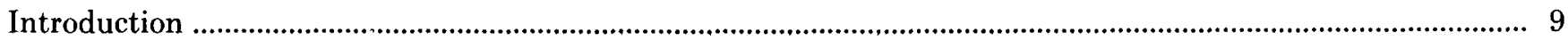

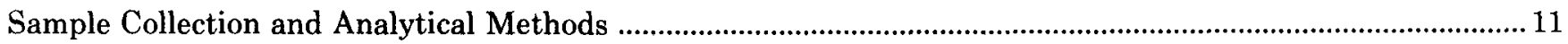

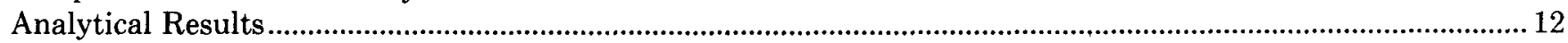

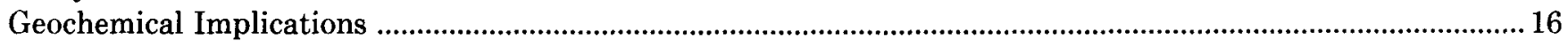

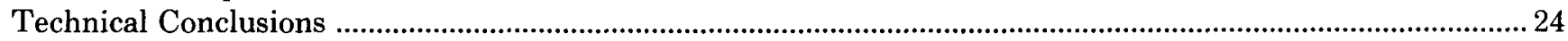

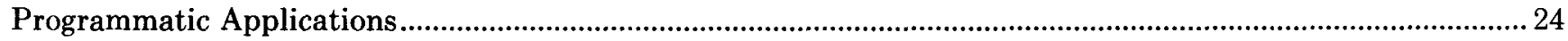

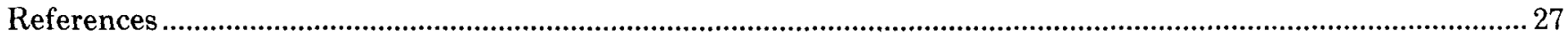

APPENDIX A-Common Evaporite Minerals and Their Formulas ..........................................................29

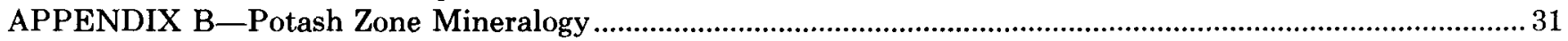

\section{Figures}

1 Ratio of $\mathrm{K} / \mathrm{Mg}$ (by weight) of fluid inclusions and weeps.............................................................................. 13

2 Ratios (by weight) of $\mathrm{Na} / \mathrm{Cl}$ vs $\mathrm{K} / \mathrm{Mg}$ of fluid inclusions, weeps, and floor-hole brines ............................. 14

3 Ratios (by weight) of $\mathrm{Mg} / \mathrm{Cl}$ vs $\mathrm{Br} / \mathrm{Cl}$ of fluid inclusions and floor holes ................................................. 14

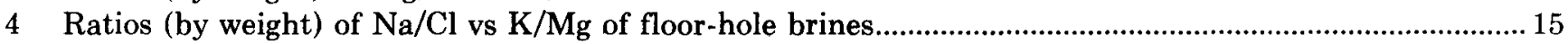

$5 \quad \mathrm{Ca}$ vs. $\mathrm{SO}_{4}$ (by weight) of fluid inclusions and floor-hole brines...............................................................18

6 Triangular diagram showing proposed direction of diagenesis resulting in alteration of existing illite-smectites and formation of more $\mathrm{Mg}$-rich silicate phases .................................................. 20

7 Scanning electron micrographs of authigenic quartz from argillaceous halite taken from

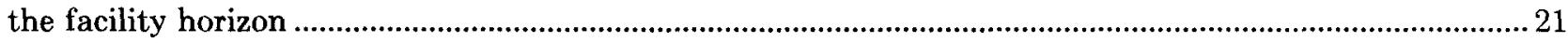

8 Scanning electron micrographs of authigenic magnesite found in argillaceous halite from

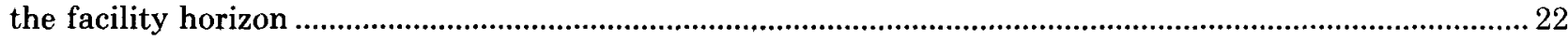

9 Summary of changes in fluid composition and accompanying mineralogical reactions ..............................22

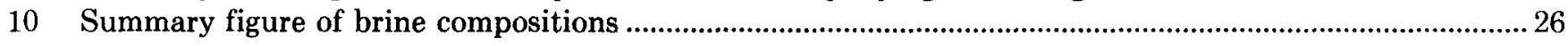

\section{Tables}

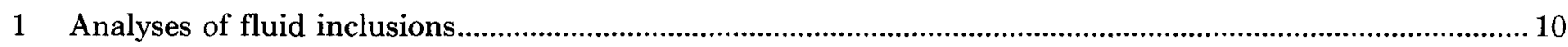

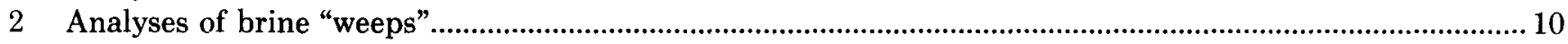

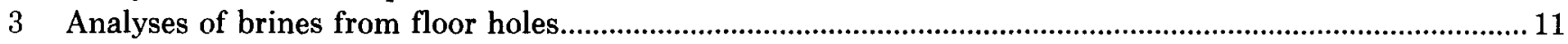

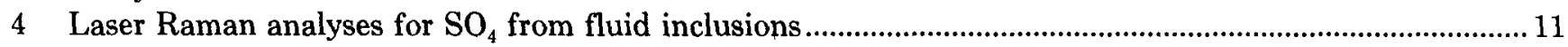

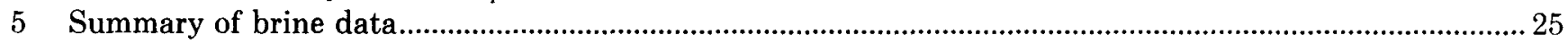




\section{Chemistry of Brines in Salt from the Waste Isolation Pilot Plant (WIPP), Southeastern New Mexico: A Preliminary Investigation}

\section{Introduction}

The Waste Isolation Pilot Plant (WIPP) is a proposed nuclear waste repository under construction for the US Department of Energy (US DOE) primarily for the long-term storage of defense-related transuranic nuclear waste. This facility is located in the lower portion of the Salado Formation (Permian), in the Delaware Basin of southeastern New Mexico, in a unit composed of flat-lying, bedded rock consisting predominantly of halite and bounded above and below by thin anhydrite marker beds. The presence of brine in WIPP salt has been a subject of concern since inception of the project, as evidenced by the reports describing the preliminary stages of the geological characterization of the facility horizon (US DOE, 1983). Moreover, it is well established that large brine reservoirs are locally present in the Castile Formation, several hundred feet below the WIPP horizon (Register, 1981). Because of the concern for radionuclide containment generated by the possibility of similar brine occurrences in the Salado Formation, we have chosen to examine the brines that have been observed in Salado halite during repository construction. The purpose of this report is to characterize the geochemistry of these brines so that we may elucidate their origins and obtain information regarding quantities of fluids as well as rates and directions of possible fluid movement. To this end, we present analytical data from macro- and microscopic brine occurrences within the WIPP facility and from the immediately adjacent halite. In addition, based on these data, we propose a geologic interpretation that explains the observed brine compositions as resulting from both short- and long-term diagenetic reactions and authigenic mineral formation.

Halitic rock in the WIPP repository horizon is composed predominantly of $\mathrm{NaCl}$ (greater than $\sim 90$ wt $\pi$; Stein, 1985a). Accessory mineralogy in the halite includes minor amounts of anhydrite, magnesite, polyhalite, and clays. A complete list of the nonargillaceous minerals referred to or identified in the samples examined in this study and their formulae are given in Appendix A. In addition, the salt contains, on the average, $\sim 0.6$ wt $\%$ intragranular water in the form of fluid inclusions (Stein, 1985b).* In primary or unrecrystallized salt, the inclusions are almost invariably microscopic, ranging in size from $<1$ to $<100$ $\mu \mathrm{m}$; they occur in the structure known as hopper crystals; i.e., bands of fluid inclusions that were trapped on the growing crystal surfaces as the salt crystals formed. The extremely high density of fluid inclusions in these bands gives these crystal outlines a milky or translucent appearance. This characteristic texture is commonly used as an indicator of salt crystals that have not been significantly recrystallized since the time of their formation. In contrast, such evidence of primary texture is absent in recrystallized salt. Recrystallization of salt results in large clear grains that contain fluid inclusions ranging in size from several hundred micrometers to several millimeters on an edge. The larger of these permitted extractions of fluid from individual inclusions and analysis of this fluid by standard wet chemical techniques. Most of the analytic results pertaining to inclusion data that are presented here refer to fluids from recrystallized salt (Table 1 ). This report also includes analyses of brines that occur in macroscopic quantities in the WIPP facility. These brines are found as "weeps," or wet places, on freshly excavated walls (data shown in Table 2), and as puddles on the facility floor or as seepage into drill holes (Table 3). Finally, we also present data on dissolved sulfate concentrations measured by laser Raman spectroscopy ( $\mathrm{Ta}$ ble 4). These data are from fluid inclusions too small to be analyzed by direct extraction of the fluid.

\footnotetext{
*This number represents an upper limit; results of the Site Validation Study (US DOE, 1983) indicate a lesser amount $(\leq 0.22 \mathrm{wt} \%$ ) of water present as fluid inclusions, with up to $0.59 \mathrm{wt} ;$ driven off by heating to $400^{\circ} \mathrm{C}$.
} 
Table 1. Analyses of fluid inclusions (in ppt)

\begin{tabular}{lllllllll} 
Sample & & & & & & & \\
Number & $\mathrm{Ca}$ & $\mathrm{Mg}$ & $\mathrm{K}$ & $\mathrm{Na}$ & $\mathrm{Cl}$ & $\mathrm{Br}$ & $\mathrm{SO}_{4}^{*}$ & Group \\
\hline I & 2.5 & 31.5 & 12.3 & 91.3 & 191 & 1.8 & 23 & II? \\
2 & 0.54 & 54.1 & 8.5 & 32.1 & 196 & 5.3 & 22.4 & I \\
3 & 0.17 & 40.4 & 6.7 & 31.3 & 161 & 2.0 & 17.8 & I \\
4 & 0.23 & 22.7 & 8.7 & 61.8 & 163 & 1.3 & 21.4 & II \\
5 & 0.18 & 15.6 & 11.5 & 81.3 & 161 & 0.9 & 24.5 & II? \\
6 & 0.21 & 21.4 & 8.1 & 66.0 & 163 & 1.8 & 26 & II \\
7 & 0.35 & 23.3 & 10.9 & 66.9 & 161 & 1.4 & 21 & II \\
$8 \mathrm{a}$ & 0.14 & 40.9 & 7.0 & 31.7 & 153 & 2.2 & 17 & I \\
$8 \mathrm{~b}$ & 0.15 & 37.9 & 6.6 & 33.7 & 153 & 2.2 & 17 & I \\
$8 \mathrm{c}$ & 0.15 & 40.8 & 7.0 & 32.6 & 162 & 2.3 & 18 & I \\
9 & 0.22 & 25.0 & 8.8 & 56.6 & 165 & 1.3 & 22 & II \\
10 & 0.18 & 22.0 & 9.3 & 66.2 & 161 & 1.2 & 22 & II \\
11 & 0.19 & 29.1 & 9.2 & 59.0 & 192 & 1.6 & 25.2 & II \\
12 & 0.29 & 15.2 & 13.1 & 92.3 & 177 & 0.0 & 23.2 & II \\
13 & 0.28 & 29.1 & 10.5 & 56.2 & 159 & 1.6 & 19 & II \\
14 & 0.23 & 28.1 & 9.2 & 52.4 & 168 & 1.5 & 18.5 & II \\
15 & 0.22 & 26.3 & 9.7 & 60.7 & 184 & 1.4 & 18.7 & II \\
16 & 0.27 & 24.2 & 9.7 & 63.8 & 171 & 1.9 & 26 & II \\
17 & 0.26 & 24.2 & 9.7 & 63.8 & 172 & 1.4 & 19.5 & II \\
18 & 0.31 & 15.7 & 6.4 & 78.5 & 167 & 0.0 & 17.4 & II
\end{tabular}

* $\mathrm{SO}_{4}$ from ion chromatography; compare to $12.8 \mathrm{ppt}$ (avg) $\mathrm{SO}_{4}$ from laser Raman results.
Table 2. Analyses of brine "weeps" (in ppt)

\begin{tabular}{ccccccc}
$\begin{array}{c}\text { Sample } \\
\text { Number }\end{array}$ & $\mathrm{Ca}$ & $\mathrm{Mg}$ & $\mathrm{K}$ & $\mathrm{Na}$ & $\mathrm{Cl}$ & $\mathrm{SO}_{4}{ }^{*}$ \\
\hline 1 & 0.30 & 18.4 & 15.4 & 75.7 & 168.2 & 12.4 \\
2 & 0.28 & 31.8 & 26.0 & 47.9 & 183.6 & 13.3 \\
3 & 0.11 & 47.3 & 19.7 & 20.8 & 187.6 & 33.8 \\
4 & 0.24 & 32.2 & 20.8 & 55.7 & 189.2 & 15.5 \\
5 & 0.27 & 17.3 & 16.1 & 78.5 & 173.8 & 13.8 \\
6 & 0.24 & 17.9 & 16.3 & 76.9 & 173.0 & 15.5 \\
7 & 0.26 & 17.5 & 15.9 & 76.8 & 177.5 & 14.3 \\
8 & 0.30 & 19.5 & 15.6 & 75.8 & 181.86 & 12.4 \\
9 & 0.40 & 19.8 & 15.3 & 75.2 & 193.8 & 9.3 \\
10 & 0.38 & 19.4 & 15.8 & 76.8 & 176.8 & 9.79 \\
11 & 0.39 & 18.4 & 16.8 & 87.2 & 194.3 & 9.54 \\
12 & 0.38 & 20.6 & 18.7 & 74.6 & 181.5 & 9.79 \\
13 & 0.48 & 23.3 & 17.6 & 81.0 & 196.3 & 7.75 \\
14 & 0.34 & 17.7 & 15.7 & 77.9 & 176.7 & 10.94 \\
15 & 0.32 & 19.6 & 17.2 & 70.9 & 176.2 & 11.63 \\
16 & 0.26 & 19.3 & 16.5 & 78.6 & 179.0 & 14.31 \\
17 & 0.37 & 20.2 & 17.5 & 78.0 & 179.1 & 10.05 \\
18 & 0.40 & 22.9 & 19.7 & 86.0 & 197.4 & 9.3 \\
19 & 0.29 & 18.2 & 16.6 & 89.5 & 200.4 & 12.8 \\
20 & 0.31 & 18.2 & 16.2 & 75.1 & 176.9 & 12.0 \\
21 & 0.36 & 17.5 & 19.9 & 76.1 & 175.2 & 10.3 \\
22 & 0.26 & 18.7 & 17.0 & 77.7 & 174.1 & 14.31 \\
23 & 0.27 & 20.3 & 17.1 & 77.6 & 175.6 & 13.78 \\
24 & 0.38 & 20.1 & 15.4 & 79.0 & 183.3 & 9.79 \\
25 & 0.26 & 19.0 & 14.2 & 71.2 & 174.9 & 14.31 \\
26 & 0.29 & 18.9 & 14.5 & 73.9 & 175.4 & 12.83 \\
27 & 0.48 & 21.9 & 15.8 & 77.9 & 185.0 & 7.75 \\
28 & 0.42 & 21.6 & 15.8 & 78.7 & 181.7 & 8.86 \\
29 & 0.32 & 20.1 & 14.6 & 72.3 & 175.2 & 11.63
\end{tabular}

${ }^{*} \mathrm{SO}_{4}$ values calculated from $\mathrm{K}_{\mathrm{Sp}}$ for gypsum 


\section{Table 3. Analyses of brine from floor holes (in ppt)}

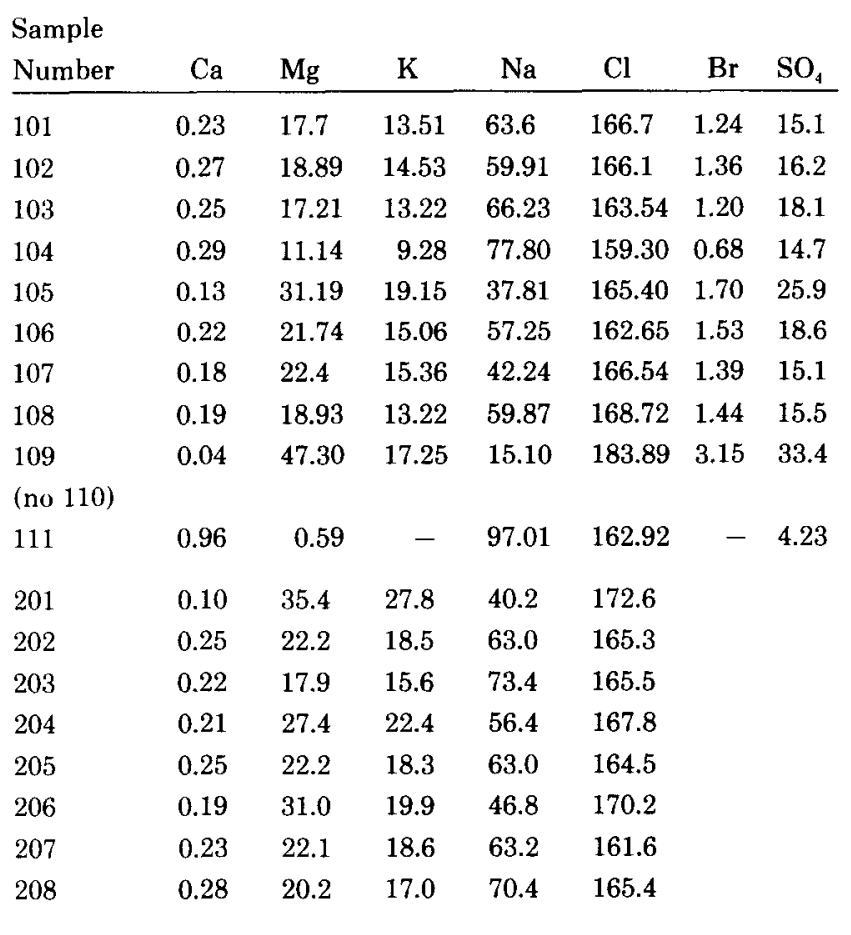

\section{Sample Collection and Analytical Methods}

The fluid inclusions from recrystallized halite in the facility horizon (at $2150 \mathrm{ft}$ ) were unusually large, often several millimeters on a side. Our extraction technique involved drilling into these inclusions by hand using an extremely small (\#65) drill bit held with a pin vice. It was necessary to continuously remove powdered salt from the sample surface and drill bit tip to prevent fluid loss into the powder as a result of capillary action. After an inclusion had been punctured in this manner, we used a preweighed syringe with a 25 -gage stainless steel needle to extract the fluid. Maximum extraction was enhanced by grinding the tip of the syringe needle flat. The syringe was then reweighed after each extraction. The amounts of inclusion fluids thus obtained ranged from
Table 4. Laser Raman analyses for $\mathbf{S O}_{4}$ from fluid inclusions

\begin{tabular}{lcccc}
$\begin{array}{l}\text { Source of } \\
\text { Sample }\end{array}$ & $\begin{array}{c}\text { Sample Depth } \\
(\mathrm{ft})\end{array}$ & $\begin{array}{c}\text { Band Ratio } \\
\left(\mathrm{SO}_{4} / \mathrm{OH}\right)\end{array}$ & $\begin{array}{r}\mathrm{SO}_{4} \\
(\mathrm{ppm})\end{array}$ & $\begin{array}{r}\text { Est Error* } \\
\left(\mathrm{ppm} \mathrm{SO} \mathrm{SO}_{4}\right)\end{array}$ \\
\hline WIPP-12 & 1125 & $<0.004$ & $<10 \dagger^{*}$ & $<500$ \\
WIPP-12 & 1125 & $<0.007$ & $<40 \dagger^{+}$ & $<500$ \\
WIPP-12 & 1692 & 0.085 & $7900 \ddagger$ & \pm 300 \\
WIPP-12 & 1692 & 0.086 & $8000 \ddagger$ & \pm 300 \\
WIPP-12 & 1692 & 0.082 & $7600 \ddagger$ & \pm 300 \\
Facility & & & & \\
Horizon & 2150 & 0.140 & 13200 & \pm 2600 \\
DOE-1 & 2297 & 0.182 & 17300 & \pm 900 \\
WIPP-12 & 2483 & 0.120 & $11300 \dagger$ & \pm 600 \\
WIPP-12 & 2483 & 0.113 & $10600 \dagger$ & \pm 600 \\
WIPP-12 & 2483 & 0.118 & $11100 \dagger$ & \pm 600 \\
WIPP-12 & 2483 & 0.105 & $9900 \dagger$ & \pm 600 \\
WIPP-12 & 2483 & 0.107 & $10100 \dagger$ & \pm 600 \\
WIPP-12 & 2741 & 0.088 & $8200 \dagger$ & \pm 700 \\
WIPP-12 & 2741 & 0.088 & $1000{ }^{\circ}$ & \pm 3400 \\
DOE-1 & 3374 & 0.104 & 9800 & \pm 700 \\
DOE-1 & 3708 & 0.110 & 10400 & \pm 1100 \\
DOE-1 & 3709 & 0.038 & 3400 & \pm 700 \\
DOE-1 & 4031 & 0.036 & $3200 \dagger$ & \pm 1300 \\
DOE-1 & 4031 & 0.100 & $9400 \dagger$ & \pm 1300
\end{tabular}

${ }^{*} 90^{\prime}$ " confidence

+ different fluid inclusions

$\ddagger$ same fluid inclusion

$\sim 10$ to $\sim 100 \mathrm{mg}$. These fluids were injected into small preweighed polyethylene bottles; after each extraction, the syringe was rinsed repeatedly with distilled, deionized water into the bottle until it contained $\sim 4 \mathrm{~mL}$ of liquid. The bottle was weighed again, and the difference used to determine the dilution factor required to compute the initial solution compositions (i.e., those of the inclusion fluids).

The brines appearing in macroscopic quantities in the drifts were collected by several methods. Where sufficient quantity was available, as in shallow floor holes and puddles on the floor, amounts of 10 to $20 \mathrm{~mL}$ were taken directly into a syringe, filtered through a $0.2-\mu \mathrm{m}$ filter, and placed in prewashed polyethylene bottles. In deeper holes, a length of Tygon tubing was used to siphon water to the surface, after which the water was filtered into clean polyethylene bottles, also using the $0.2-\mu \mathrm{m}$ filter paper and syringe. 
The weeps along the drift walls required a more efficient collection technique. At locations where brines were seen to be oozing from the walls of the drift, a total of 52 holes $(\sim 13 / 8$ in. diameter, $\sim 8$ to 10 in. long) were drilled using a small hand-held rock drill. A numbered, prewashed, preweighed, fabriccovered sponge was inserted into each hole. The configuration was designed to minimize the air space in the hole surrounding the sponge. The holes were then sealed with pieces of Parafilm and black rubber laboratory stoppers. These sponges were left in place for periods of 6 weeks to 2 months, at which time about three-fourths of the sponges were observed to be either "moist" or "wet," and many of the plugs were surrounded by efflorescences identical to those associated with the weeps on the walls. Upon retrieval, the sponges were placed in correspondingly numbered, preweighed polyethylene bottles. The bottles now containing the damp sponges were then reweighed. The difference between the "before" and "after" weights is attributed to brine that was soaked up by the sponges. In general, measurable quantities of brines were recovered by this technique. Amounts of brine collected in this manner ranged between $0.1 \mathrm{~g}$ and several grams. The brines were extracted by putting them in a large excess of deionized water. Although in most cases the fabric overcoat protected the sponges from contamination with rock dust produced by the drilling, a few analyses produced unreasonably high $\mathrm{Ca}, \mathrm{Na}, \mathrm{Cl}$, and $\mathrm{SO}_{4}$ values, leading us to conclude that these samples were contaminated.

Cations from all fluid samples were analyzed by DC plasma emission spectroscopy, using a Spectraspan IIIB set up for simultaneous analysis of $\mathrm{K}, \mathrm{Na}$, $\mathrm{Ca}$, and $\mathrm{Mg}$. A total of $\sim 1 \mathrm{~mL}$ of each original sample (after dilution) was consumed in the analysis for cations. In several cases (Samples 1, 2, 7, 12, and 18; Table 1) the dilution factors were so large that the accuracy of these numbers is questionable. Samples $8 \mathrm{a}, \mathrm{b}$, and $\mathrm{c}$ (Table 1) are successive samples from a single large inclusion; these analyses show that, overall, our technique apparently introduces errors that are small in comparison to the differences between inclusions. Beyond this it is not possible to present replicate analyses for the inclusion samples because of limited amounts of fluids. However, Spectraspan data typically are reproducible to $\pm 5 \%$, and so this is a measure of the probable precision of these data. For these fluids, $\mathrm{SO}_{4}^{2}$ and $\mathrm{Br}^{-}$were analyzed using a Dionix 2000i ion chromatograph (Merrill, 1985). Chloride was determined using a Buchler Chloridometer and consumed $\sim 200 \mu \mathrm{L}$ of each diluted sample. A charge balance of these results shows an excess of negative charge, suggesting that $\mathrm{HCO}_{3}^{-}$and $\mathrm{HS}^{-}$are of only minor importance. The major anion components are assumed to be $\mathrm{Cl}^{-}, \mathrm{Br}^{-}$, and $\mathrm{SO}_{4}^{2-}$. It is to be emphasized that, in comparing these analyses with data in the literature, care should be taken to check the units. These brines have a density of $\sim 1.2 \mathrm{~g} / \mathrm{cm}^{3}$, so that a comparison of analyses given in units of $\mathrm{g} / \mathrm{kg}$ with $\mathrm{g} / \mathrm{L}$ will automatically result in a $20 \%$ discrepancy.

In addition, a study was recently completed of the fluid inclusions in salt from the lower Salado and underlying Castile Formations using freezing point depression analysis and laser Raman spectroscopy. Details of these techniques and results can be found in Stein (1985a) and Tallant et al (1983), and will not be discussed here. The data are included (Table 4), however, because one of the samples analyzed by the laser Raman technique was taken in the WIPP facility horizon and the results are compared to other analyses (this study) of samples taken from the same horizon.

Stein (1985b) describes the mineralogical analysis of two cores taken in the WIPP facility, one extending $50 \mathrm{ft}$ up into the roof and the other penetrating $50 \mathrm{ft}$ below the floor. Forty-seven samples from these cores were analyzed for non- $\mathrm{NaCl}$ mineral components by separation of water- and EDTA-insoluble residues. The former consist of quartz, magnesite, anhydrite, polyhalite, and clays, with minor gypsum and alkali feldspar (tentatively identified). Treatment with EDTA removes carbonates and sulfates (Bodine and Fernalld, 1973), leaving a silicate residue composed primarily of quartz and clays, the nature of which was determined by scanning electron microscopy and conventional x-ray diffraction techniques. Additional details regarding the silicate mineralogy of samples from the WIPP facility horizon will appear in a separate report (Krumhansl et al., in preparation). A more detailed examination of an argillaceous sample taken from an exposed clay seam near Room $J$ in the WIPP workings is also presently under way, using scanning and transmission electron microscopy, $\mathrm{x}$-ray and electron diffraction, and semiquantitative energy dispersive $\mathrm{x}$-ray analysis.

\section{Analytical Results}

An examination of all the fluid inclusion analyses showed considerable compositional variation. In Figures 1 through 4 we show these compositions plotted as element ratios. We chose this method of data presentation primarily because (1) it minimizes inaccuracies resulting from the large and variable dilution factors employed during chemical analysis, and (2) it simplifies graphical representation of the reduced data. 


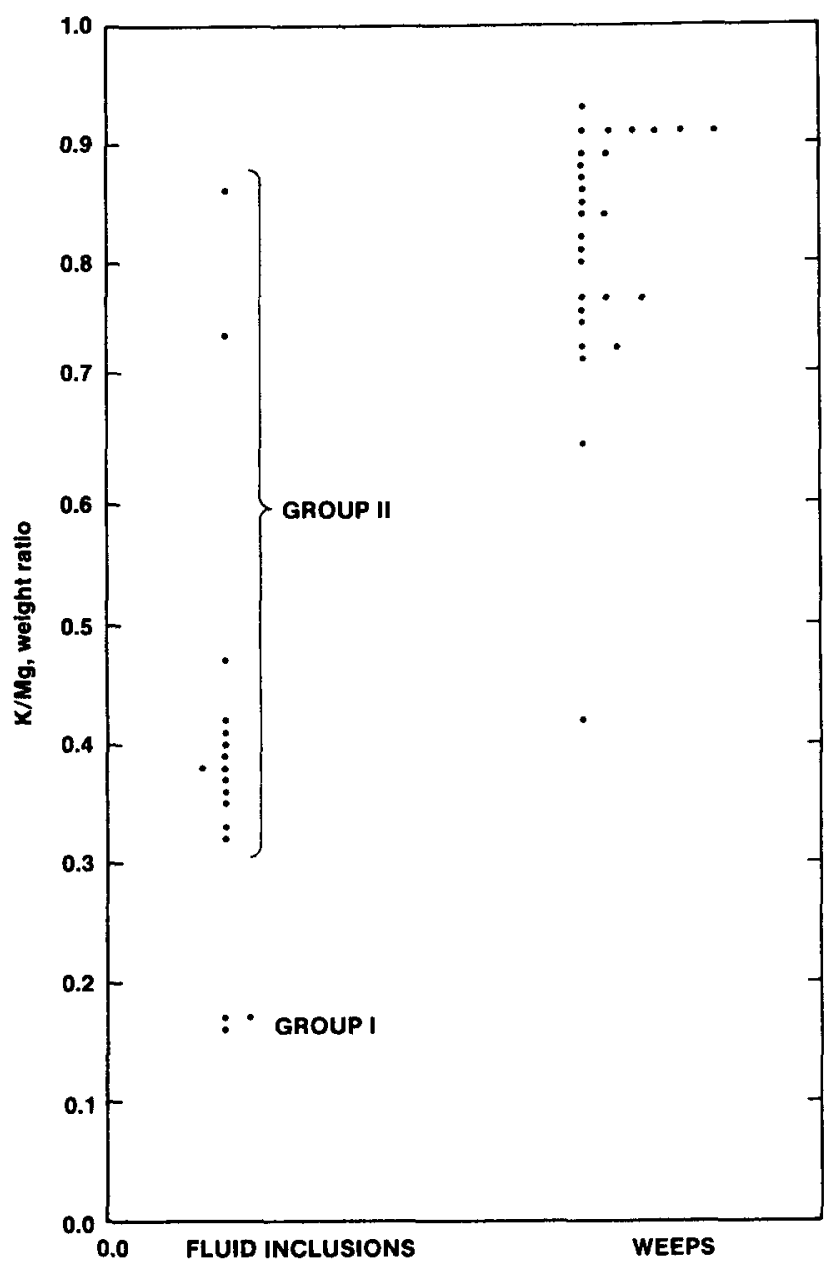

Figure 1. Ratio of $\mathrm{K} / \mathrm{Mg}$ (by weight) of fluid inclusions and weeps 


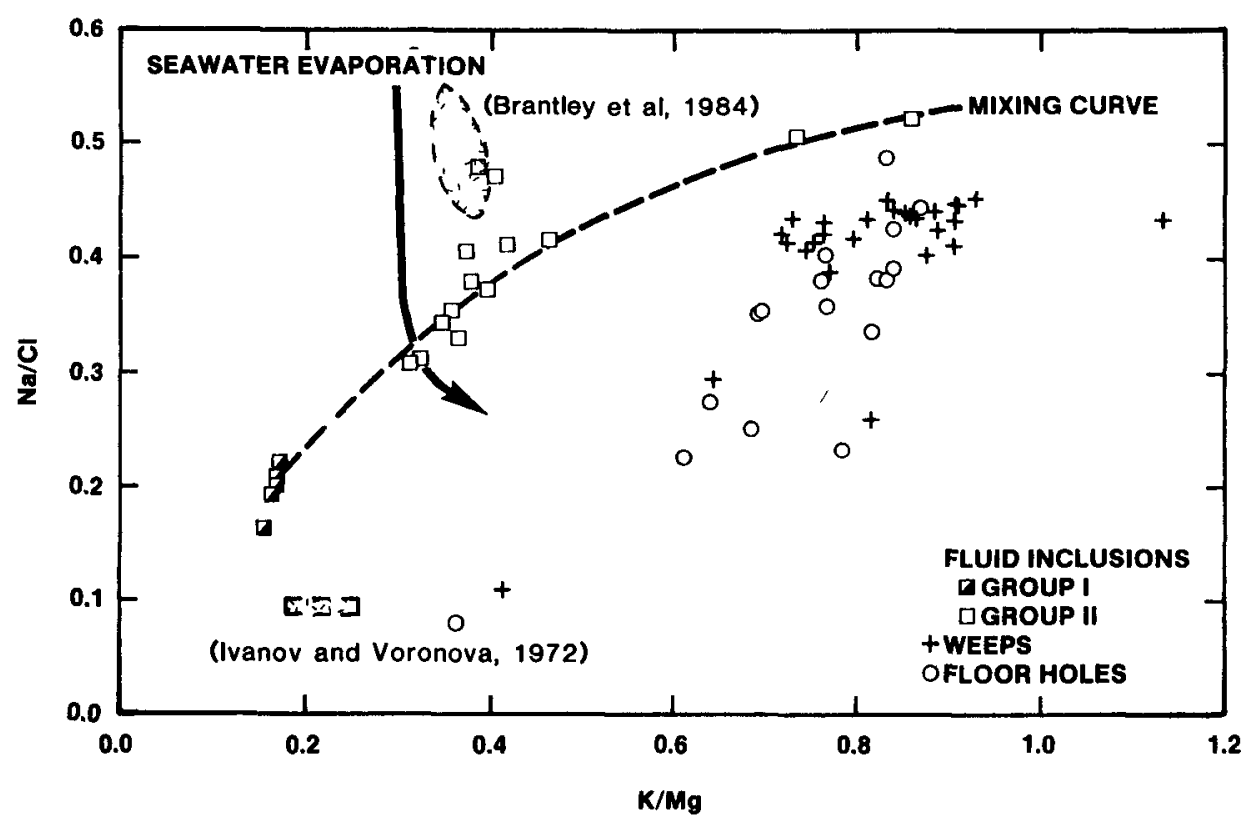

Figure 2. Ratios (by weight) of $\mathrm{Na} / \mathrm{Cl}$ vs $\mathrm{K} / \mathrm{Mg}$ of fluid inclusions, weeps, and floor-hole brines. (See text for explanation of mixing curve and distinction between Groups I and II. As noted in the figure, the stippled areas represent (1) data from a modern evaporite environment (from Brantley et al., 1984), and (2) seawater analyses at the point of sylvite precipitation (Ivanov and Voronova, 1972)).

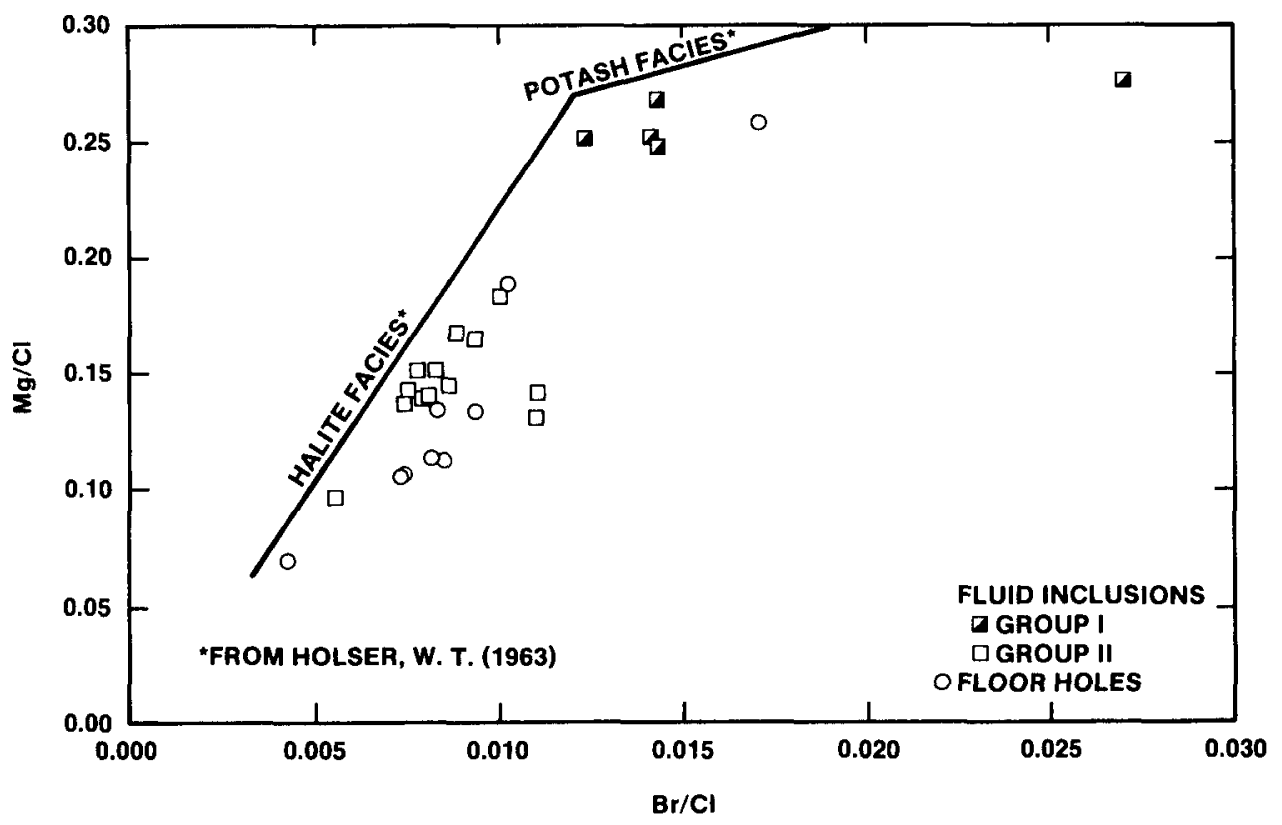

Figure 3. Ratios (by weight) of $\mathrm{Mg} / \mathrm{Cl}$ vs $\mathrm{Br} / \mathrm{Cl}$ of fluid inclusions and floor holes. (The lines denoting compositions of the halite and potash facies have been taken from Holser (1963).) 


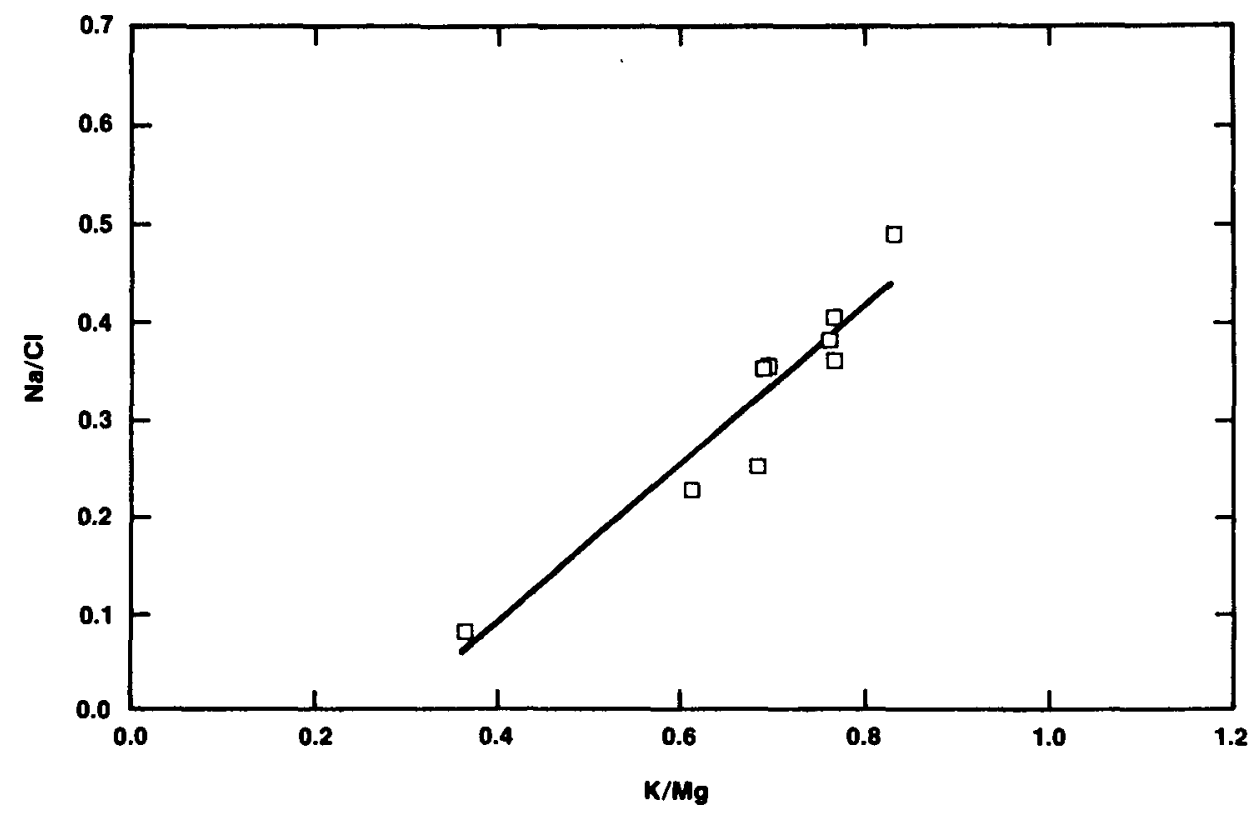

Figure 4. Ratios (by weight) of $\mathrm{Na} / \mathrm{Cl}$ vs $\mathrm{K} / \mathrm{Mg}$ of floor-hole brines. (A linear regression through these points $(r=0.95)$ suggests a relationship between sample composition and distance of sampling (in the vertical direction) from Marker Bed 139. Decreasing $\mathrm{K} / \mathrm{Mg}$ and $\mathrm{Na} / \mathrm{Cl}$ values are tentatively correlated with increasing distance from Marker Bed 139.)

Looking only at the $\mathrm{K} / \mathrm{Mg}$ ratios* (as shown in Figure 1), we initially distinguish two compositionally distinct groups of fluid inclusions, both of which differ from compositions of the macroscopic brine accumulations. Figure 2 shows the fluid inclusion compositions plotted as ratios of $\mathrm{Na} / \mathrm{Cl}$ to $\mathrm{K} / \mathrm{Mg}$, thus verifying their bimodal distribution when all the major components in solution are considered. We designated the inclusions characterized by low $\mathrm{Na} / \mathrm{Cl}$ and $\mathrm{K} / \mathrm{Mg}$ values as Group I, and inclusions with higher $\mathrm{Na} / \mathrm{Cl}$ and $\mathrm{K} / \mathrm{Mg}$ values as Group II. To summarize the data briefly, the compositions of the Group I inclusions all fall very close to the point where $\mathrm{K} / \mathrm{Mg}=0.15, \mathrm{Na} / \mathrm{Cl}$ $\simeq 0.2$. The compositions of the Group II inclusions are much more diverse and cover the range from $\mathrm{K} / \mathrm{Mg}$ $\simeq 0.3$ to $\sim 0.8$ and $\mathrm{Na} / \mathrm{Cl} \simeq 0.3$ to $\sim 0.5$.

The weep data (Figure 2) also show considerable variation, but with a different trend as compared to the fluid inclusions. The weep analyses range from $\mathrm{K} / \mathrm{Mg}=0.4$ to $\sim 1.15$ and $\mathrm{Na} / \mathrm{Cl}$ between 0.1 and 0.45 . Most of the weep analyses cluster in the region around $\mathrm{K} / \mathrm{Mg}=0.8, \mathrm{Na} / \mathrm{Cl}=0.4$. The weep fluids have $\mathrm{Na} / \mathrm{Cl}$ values in approximately the same range as the Group II fluid inclusions, although the average $\mathrm{K} / \mathrm{Mg}$ value for the weeps is higher. The Group I inclusions are characterized by consistently lower values of both $\mathrm{Na} / \mathrm{Cl}$ and $\mathrm{K} / \mathrm{Mg}$ as compared to the weeps.

Finally, the floor-hole analyses are also presented in Figure 2. These data lie approximately within the same compositional range as the weeps $(\mathrm{K} / \mathrm{Mg}=0.35$ to $\sim 0.8, \mathrm{Na} / \mathrm{Cl} \simeq 0.05$ to $\sim 0.45$ ). The floor-hole data clearly define a linear trend, with a more even distribution of data points than for the weeps.

If the two compositional extremes of the fluid inclusion analyses are taken as endpoints, the $\mathrm{Na} / \mathrm{Cl}$ and $\mathrm{K} / \mathrm{Mg}$ values of various mixtures of these compositions yield the "mixing line" that is represented by the dashed line in Figure 2. The curvature of this line is due to our use of the element ratios and not to the absolute element concentrations. The apparent fit of the real data from the fluid inclusions to this mixing line suggests a possibly significant geological correlation. It is important to note here that the use of the term "mixing line" refers only to the mathematical construction of this line and must not be construed as an implication of mechanism; e.g., a true mixing of two discrete fluids to obtain the observed brine compositions. Their origins are discussed in detail in the following section.

\footnotetext{
${ }^{*}$ Ratios of element weights as ppt
} 
A previous study (Stein, 1985a) using laser Raman spectroscopy found sulfate analysis in very small $(<10 \mu \mathrm{m})$ fluid inclusions from the WIPP facility horizon to be (1) variable, (2) generally below what would be expected for halite facies brines, and (3) suggestive of polyhalite formation. When the larger inclusions were analyzed by the direct fluid extraction technique, sulfate values substantially in excess of those obtained using the laser Raman technique (shown in Table 4) were found.

The laser Raman sulfate analyses of these very small fluid inclusions, some of which were in hopper crystals, are lower than the lowest sulfate value obtained by ion chromatography from an inclusion in recrystallized salt from the same horizon (e.g., 13 vs. $17 \mathrm{ppt} \mathrm{SO}_{4}$ ). Whether this results from a systematic depletion in $\mathrm{SO}_{4}$ in the smaller inclusions, or whether the Raman spectroscopic analyses had a systematic error introduced by the absence of $\mathrm{Mg}$ and $\mathrm{K}$ in the standard solutions remain topics for future research.

\section{Geochemical Implications}

It is not yet known if the minute fluid inclusions in hopper crystals were mobilized by localized salt deformation, thereby coalescing into these larger inclusions, or if localized areas containing high concentrations of inclusions actually initiated recrystallization without the influence of large-scale mechanical deformation. Nor is it clear how the weeps relate to the various types of inclusions. In addition, the ultimate origins of all of the observed fluids have not yet been established with certainty. Several hypotheses are discussed, including an origin attributing inclusion fluids to the dehydration of primary gypsum, trapped Permian seawater, and/or water released in various reactions involving clay mineral diagenesis (e.g., the conversion of normal sedimentary clays to a suite of Mg-enriched sheet silicates such as talc or saponite). While information on fluid compositions does not answer all of the questions posed above, we attempt to shed some light on the magnitude of possible fluid inclusion movement within the waste repository and to provide a historical perspective from which to address the question of fluid migration in this waste repository.

As a starting point to explain how these diverse fluids originated, consider the evaporation of seawater. Isotopic data from fluid inclusions from the WIPP facility horizon are compatible with an early halite-facies origin (Knauth, 1985, pers. comm.). Compositionally these fluids were compared (Figure 2) with brine analyses from halite-facies deposition in a modern basin (Brantley et al., 1984) and with what is expected for the onset of both halite and sylvite precipitation (Ivanov and Voronova, 1972). The solid line (Figure 2) shows the changing $\mathrm{Na} / \mathrm{Cl}$ and $\mathrm{K} / \mathrm{Mg}$ ratios of evaporating seawater as calculated from salts precipitated during the classical experiment of Usiglio (1849), along with the present-day seawater analyses of Brantley et al., (1984). The endpoint of this line represents the final brine composition of Usiglio's experiment; e.g., when very little fluid is left. It is proposed that this brine resembles what would have existed at the time evaporites were forming at the stratigraphic level of the present-day WIPP site. Apparently further modification of the brines occurred, however, because the observed compositions differ greatly from those noted by Usiglio for the straightforward evaporation of seawater.

Further support for this hypothesis comes from the work of Holser (1963). He illustrated the evolutionary stages of evaporite-forming brines by plotting their compositions as ratios of $\mathrm{Br}^{-} / \mathrm{Cl}^{-}$vs $\mathrm{Mg}^{2+} / \mathrm{Cl}^{-}$, assuming no postdepositional mineral reactions. When our data for fluid inclusions and floor holes are plotted according to this scheme* (Figure 3), two points are immediately evident. First, most of the floor-hole samples and the Group II inclusions apparently originated in an environment that is consistent with the mineralogy observed at the WIPP stratigraphic level; e.g., that of the halite facies. Second, the Group I inclusions should have originated along with other highly soluble minerals characteristic of a potash-facies environment, (e.g., sylvite, carnallite, langbeinite, etc.; refer to Appendix B). This mineral assemblage, however, is conspicuously absent in the halite in which these inclusions are found. ${ }^{+}$This apparent contradiction may be resolved by assuming that compositional modifications of brines occurred after cessation of evaporite deposition, thus further supporting a model that extends considerably beyond one based on simple seawater evaporation.

\footnotetext{
*One of Holser's values for the New Mexico Permian differs greatly from our analyses (Holser's point where $\mathrm{Mg} / \mathrm{Cl}=0.171, \mathrm{Br} / \mathrm{Cl}=0.0035$ ). There is, however, good agreement between some of our data and Holser's analyses of Kansas Permian and Ontario Silurian fluids
}

†This mineral assemblage is restricted to the McNutt Potash Member, which is found several hundred feet up in the stratigraphic sequence, above the WIPP facility horizon, and is characterized by the potash minerals listed in Appen$\operatorname{dix} B$. 
Since previous work indicated that polyhalite formation may significantly affect brine chemistry, it is informative to explore how this would modify the brine from Usiglio's experiments. Qualitatively, the reaction* may be written as

2 gypsum (or anhydrite) $+2 \mathrm{~K}^{+}+\mathrm{Mg}^{2+}+2 \mathrm{SO}_{4}^{2-} \rightarrow$ polyhalite \pm water

thus consuming twice as much potassium as magnesium and shifting brine compositions to the left in Figure 2. Moreover, although polyhalite occurs with the suite of potash minerals listed in Appendix B, its presence alone does not necessarily indicate a potashfacies environment; it occurs commonly as a secondary mineral requiring only the reaction between a latestage highly concentrated brine and calcium sulfate (gypsum or anhydrite).

Mineralogically, the sequence in Eq (1) is entirely plausible. Anhydrite, a logical source of $\mathrm{Ca}$ and $\mathrm{SO}_{4}$, is present in abundance as either discrete layers such as Marker Bed 139 (MB-139) immediately beneath the facility floor, or finely disseminated in other portions of the halite. Polyhalite, too, is present; it occurs ubiquitously as a secondary mineral, sometimes noted as a replacement of anhydrite, and it is occasionally seen as a daughter mineral in the larger fluid inclusions as well. We may then postulate the formation of the hopper salt inclusions and the Group I fluid inclusion compositions as having arisen from the reaction of a late-stage halite-facies brine (represented by the approximate end-point composition of Usiglio's experiment, as shown in Figure 2) with either gypsum or anhydrite to form polyhalite and a different brine having a lower $\mathrm{K} / \mathrm{Mg}$ ratio (represented by the Group I analyses). Because these fluid inclusions occur in close proximity to polyhalitic halite, and because all of these inclusions were taken from recrystallized halite, we infer that halite recrystallization and polyhalite formation must have occurred very nearly simultaneously and must have involved minimal fluid movement. Moreover, the brine compositions indicate that these processes occurred late in the evaporative cycle. Seawater must be reduced to $\sim 30 \%$ and $\sim 10 \%$ of the original volume to precipitate gypsum and halite, respectively (Berner, 1971); thus we suggest that the Group I fluid inclusion compositions result from the reaction of a late-stage evaporative brine with gypsum

*(Refer to Figure 2.) This reaction results in a decreased $\mathrm{K} / \mathrm{Mg}$ ratio, consumption of sulfate, and slight increases or decreases in the $\mathrm{Na} / \mathrm{Cl}$ ratio depending respectively on whether halite dissolves or precipitates. or anhydrite to form polyhalite, perhaps concomitantly with halite precipitation. That this whole process in fact occurred soon after halite-facies deposition is confirmed by the age dates in excess of $200 \mathrm{~m} . \mathrm{y}$. BP (Brookins, 1980) obtained on polyhalites from WIPP samples.

A second mineralogical reaction requiring consideration is the formation of magnesite, a mineral occurring frequently in samples taken within and adjacent to the WIPP stratigraphic horizon. In cores extending $\sim 50 \mathrm{ft}$ above and below the WIPP facility, it was found that polyhalite occurred in 4 out of 26 samples, while magnesite was reported 20 times. Initially the evaporite sequence probably contained calcium carbonate derived from indigenous biologic activity, as suspended material washed in from the reefs on the margins of the evaporite basin, or as a minor component in the argillaceous debris derived from adjacent land masses. In any case the magnesium-rich brines evidently consumed the calcium carbonate according to the reaction:

$\mathrm{CaCO}_{3}+\mathrm{Mg}^{2+}+\mathrm{SO}_{4}^{2-} \rightarrow \mathrm{CaSO}_{4}+\mathrm{MgCO}_{3}$

In contrast to polyhalite formation, this would shift the $\mathrm{K} / \mathrm{Mg}$ ratio to higher values. At the same time the solute content of the fluid would decrease, causing halite dissolution and an increase in the $\mathrm{Na} / \mathrm{Cl}$ ratio in the fluids. ${ }^{+}$We suggest that the Group II inclusions originated in this manner. Because these inclusions are found in recrystallized salt containing polyhalite, it is inferred that this reaction, too, occurred early in the diagenetic sequence and involved only short-range fluid movement. ${ }^{\ddagger}$ However, this reaction did not occur to the extent that $\mathrm{Ca}$-rich brines were formed, as was the case in the Palo Duro Basin, for example (Roedder, pers. comm., 1985). Instead, the brine-to-calcite ratio must have been sufficiently high so that the $\mathrm{Ca}$ liberated was precipitated by a large excess of sulfate, forming either gypsum or anhydrite. Support for this process can be found in the fact that, although these brines have a molar ratio of calcium to sulfate substantially less than 1 , all of the brines are approximately equilibrated with calcium sulfate (Figure 5).

\footnotetext{
${ }^{\dagger}$ At this stage of evaporation, seawater contains more chloride than sodium. Consequently, addition of equal amounts of $\mathrm{Na}$ and $\mathrm{Cl}$ during halite dissolution causes the $\mathrm{Na} / \mathrm{Cl}$ ratio to rise.

${ }^{\ddagger}$ Note that the distances of fluid migration in the formation of polyhalite are not known but assumed (based on the evidence presented here) to be small, perhaps less than a few meters.
} 


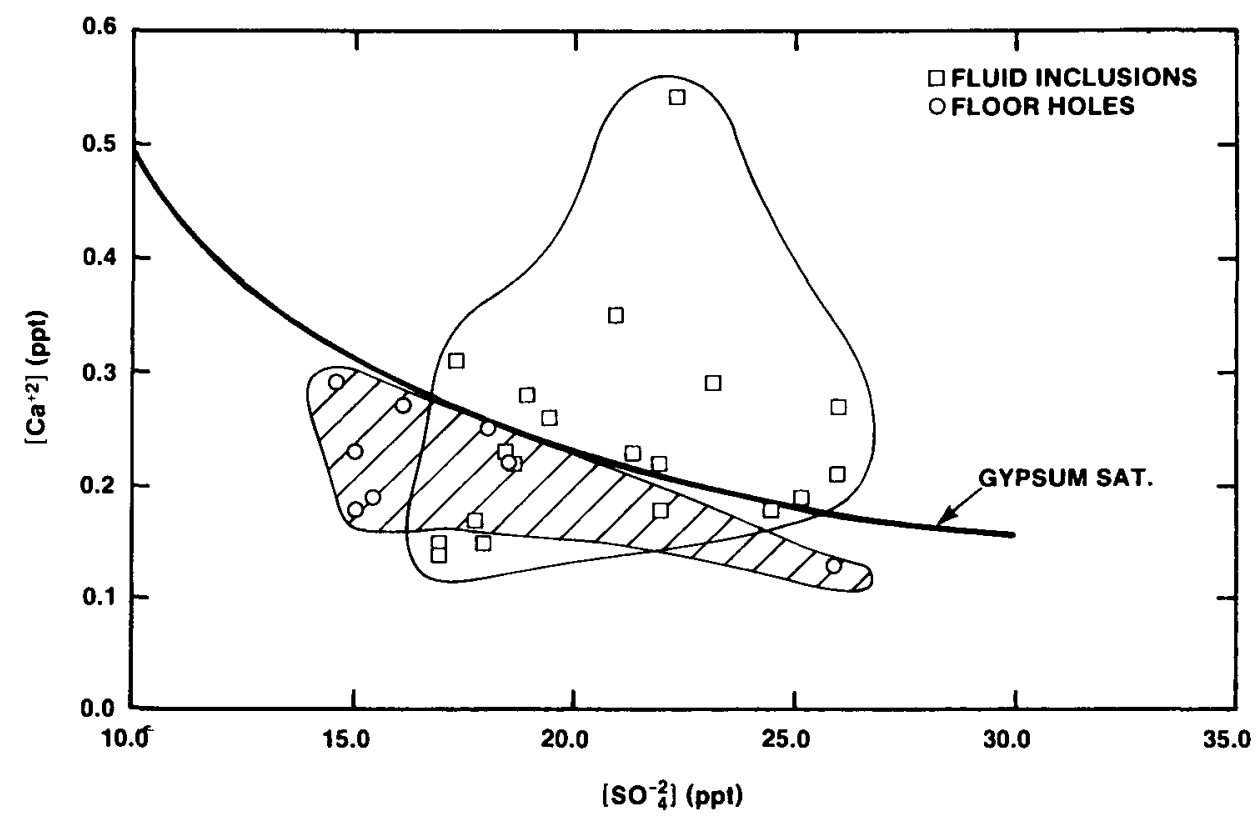

Figure 5. Ca vs. $\mathrm{SO}_{4}$ (by weight) of fluid inclusions and floor-hole brines. (The curved line represents the calculated values for gypsum saturation at $25^{\circ} \mathrm{C}$.)

Based on the data presented so far, the following model is advanced to explain the variations in brine compositions as seen in the fluid inclusions:

1. The stratigraphic section in the immediate vicinity of the WIPP facility horizon at the time of evaporite deposition contained a significant and unspecified amount of gypsum and a small amount of calcium carbonate (calcite or aragonite). These transformed to form, respectively, polyhalite or magnesite, thus altering the brine composition in close proximity to the reacting mineral grains.

2. As P-T conditions changed with increasing burial depth, gypsum transformed to anhydrite. This resulted in a volume reduction, liberation of fresh water, and possible localized deformation (including recrystallization) of the adjacent rock salt.

3. This water may have mixed with earlier brines whose compositions had been modified by formation of polyhalite, magnesite, or both. These solutions were then trapped as the larger inclusions in the recrystallized salt. Two populations of inclusions are definable on the basis of composition; however, the processes affecting these compositions are not mutually exclusive. Therefore it is not surprising that the two fields shown in Figure 2 partially overlap.
The relative importance of these two primary processes should be related to the frequency of occurrence of the reaction products (e.g., polyhalite vs. magnesite). Although quantitative data are not currently available, the many observations of magnesite in samples taken within and adjacent to the WIPP facility compare favorably with the greater abundance of Group II inclusions.

Considering next the brines from the weeps and floor-hole samples (Tables 2 and 3, Figures 2 through 4 ), it is evident that additional diagenetic processes must have been involved since their compositions preclude an origin from fluid inclusion migration in the perturbed stress field surrounding the mine openings. Instead, the weep and floor-hole brine compositions appear to bear some relationship to the anhydrite marker beds found above and below the WIPP facility. Three lines of evidence lend credence to this tentative correlation:

(1) Holes drilled into these marker beds will frequently fill with brine, whereas holes that fail to penetrate the marker beds commonly remain dry.

(2) The data in Figure 4 plot as a straight line. It appears that samples taken farthest away (in the vertical direction) from MB-139 correspond to the lowest $\mathrm{Na} / \mathrm{Cl}$ and $\mathrm{K} / \mathrm{Mg}$ values, while those samples with increasingly higher $\mathrm{Na} / \mathrm{Cl}$ and $\mathrm{K} / \mathrm{Mg}$ values came from holes closer to or penetrating the marker bed. 
(3) The calcium sulfate ion product for the floorhole samples closely parallels the saturation curve for gypsum, whereas for the fluid inclusions the ion product shows considerable scatter. It is inferred that this contrast arises because the fluids collected from the floor holes have recently been in contact with calcium sulfate relative to the inclusion compositions that have been modified by the gypsumanhydrite transition, polyhalite and magnesite formation, and possibly even bacterial sulfate removal. It is important to reiterate that this correlation is very speculative, and much more information is required for its validation.* This is emphasized by the fact that there are also many dry holes that penetrate the anhydrite marker beds.

Abundant field evidence supports the occurrence of silicate diagenesis. Bodine (1978), for example, has reported that clays in Salado halite are unusual in that they are depleted in $\mathrm{Al}$ and $\mathrm{Ca}$, and enriched in $\mathrm{Mg}$. In samples taken from a complete core through the Salado Formation and from the uppermost part of the underlying Castile Formation, he also finds that the clay mineral assemblage includes such $\mathrm{Mg}$-rich species as talc; saponite; clinochlore; serpentine; and Mgrich, mixed-layer, smectite-illite clays. This mineralogic picture was also confirmed by the more detailed studies carried out on samples taken above and below the WIPP horizon (Stein, 1985a).

Detailed clay mineralogy, employing electron microscopy, of a clay sample from an exposure in the WIPP facility (near Room J) is in progress. Preliminary results confirm (1) the presence of several discrete authigenic phases; (2) the enrichment of these clays in magnesium over what would be expected in normal clays derived from the midcontinent region; and (3) an abundance of sub-micron-sized euhedral crystals of magnesite in the clay seams. These observations are not surprising, since initially the clays were predominantly illitic or kaolinitic (Bodine, 1978) and certainly the brines contained an adequate amount of $\mathrm{Mg}^{2+}$ to effect the indicated alteration (Figure 6), as indicated by the high-temperature experimental work of Krumhansl (1984). We propose that the overall diagenetic mechanism for silicate phases involved displacement of octahedrally coordi-

*Plans are presently under way to obtain samples from floor holes using sampling technology that will assure known stratigraphic source of the brines. nated aluminum by magnesium, that, in turn, displaced tetrahedrally coordinated $\mathrm{Si}^{4+} .^{\dagger}$ The net result is liberation of silica to form authigenic quartz (Figure 7), which has been observed in abundance in argillaceous halite from the WIPP; consumption of magnesium, forming authigenic sheet silicates (Figure 8); and where illite was involved, liberation of potassium. The net change in solution composition is, clearly, toward increasing the $\mathrm{K}$ concentration relative to that of $\mathrm{Mg}$ (Figures 2 and 4).

Thus an explanation of the compositions of the macroscopic brine accumulations requires consideration of $\mathrm{Mg}$ uptake by solid phases during diagenetic reactions involving silicate minerals and the brines. These brines must have been in contact with the indigenous (presumably primarily illitic) clays for sufficient time for the extremely slow kinetics of roomtemperature silicate-water interactions to have altered the brine compositions. In contrast, modification of the brines that were isolated in fluid inclusions in salt were dominated by faster reaction kinetics, forming primarily the non-silicate phases polyhalite and magnesite.

We have established thus far that a simplistic seawater evaporation model does not account adequately for the variations in brine compositions described in the preceding sections. Consequently, a more complex explanation for their origin is advanced here and summarized in Figure 9. We present evidence that supports the hypothesis that the early formation of both polyhalite and magnesite is responsible for the observed deviations in $\mathrm{K}^{+}, \mathrm{Mg}^{2+}$, and $\mathrm{SO}_{4}^{2-}$ values in fluid inclusions from those in evaporating seawater, and that the $\mathrm{K} / \mathrm{Mg}$ ratio is shifted accordingly. The inversion of gypsum to anhydrite results in the addition of fresh water to the system, with the net effect of increasing $\mathrm{Na}^{+}$relative to $\mathrm{Cl}^{-}$. These three processes are assumed to have occurred very nearly simultaneously, along with halite recrystallization (which contributed no net change in the chemistry of the system). Finally, the fourth process thought to be operating more slowly than the others and for a much longer time is the uptake of $\mathrm{Mg}$ (relative to $\mathrm{K}$ ) by indigenous clays and formation of new authigenic $\mathrm{Mg}$ silicate minerals. Correspondingly, the $\mathrm{K} / \mathrm{Mg}$ ratio of coexisting fluids increases, as evidenced by the compositions of fluids from the weeps and floor holes.

\footnotetext{
${ }^{\dagger}$ Because gibbsite, corundum, and other hydrous $\mathrm{Al}$ oxides do not appear in the $\mathrm{x}$-ray diffraction traces, we submit that the diagenetic reactions must occur in such a way that $\mathrm{Al}$ is retained (i.e., conserved) in the structures of the sheet silicates and that silica is liberated in accordance with the observed authigenic quartz.
} 


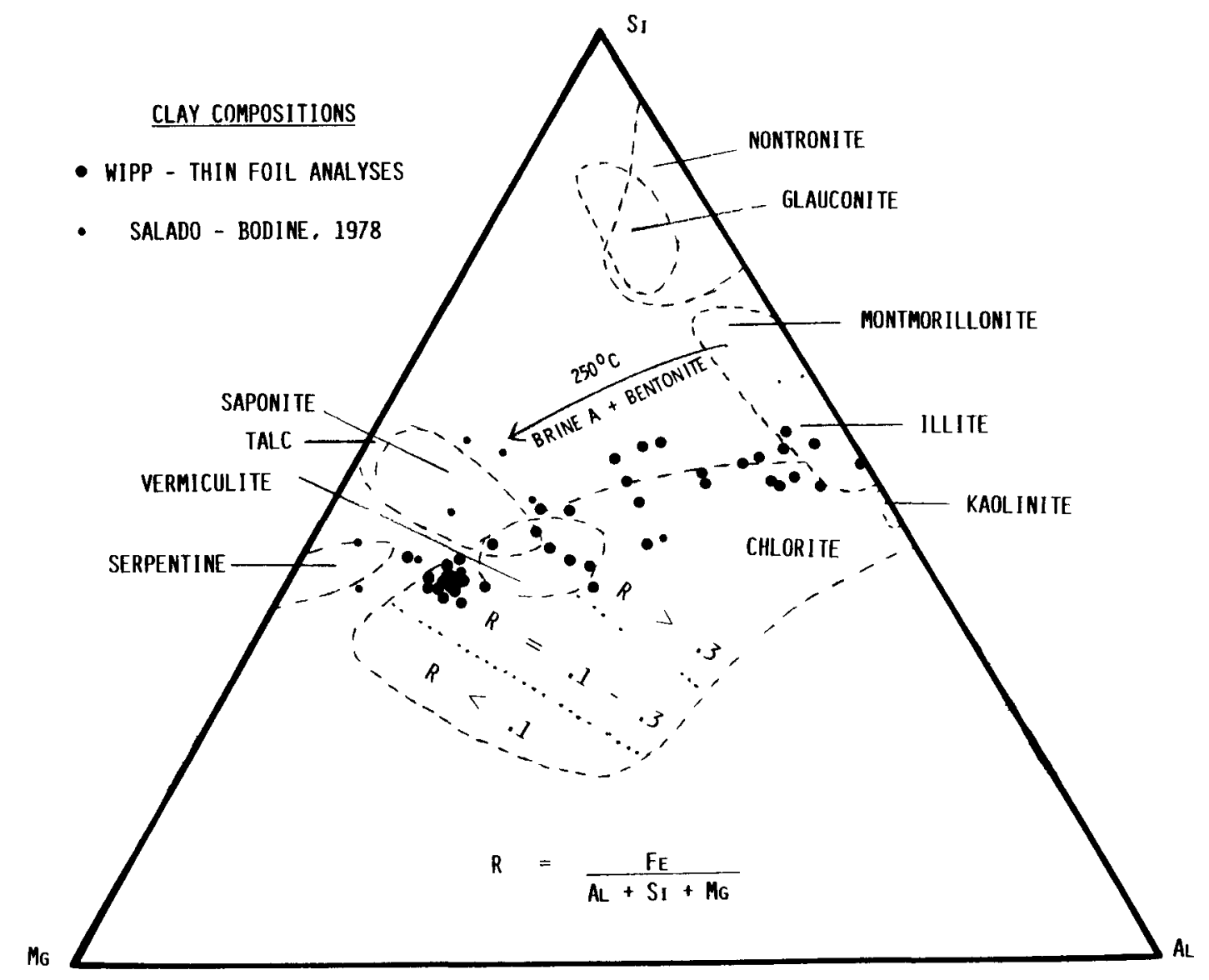

Figure 6. Triangular diagram showing proposed direction of diagenesis resulting in alteration of existing illite-smectites and formation of more $\mathrm{Mg}$-rich silicate phases. (The $\mathrm{R}$-values refer to chlorite compositions taken from the literature; with the exception of four points, the thin-foil analyses of WIPP clays are too iron-deficient to be classified as chlorite. The composition of Brine A can be found in Table 5; see Krumhansl (1984) for details of hydrothermal work.) 


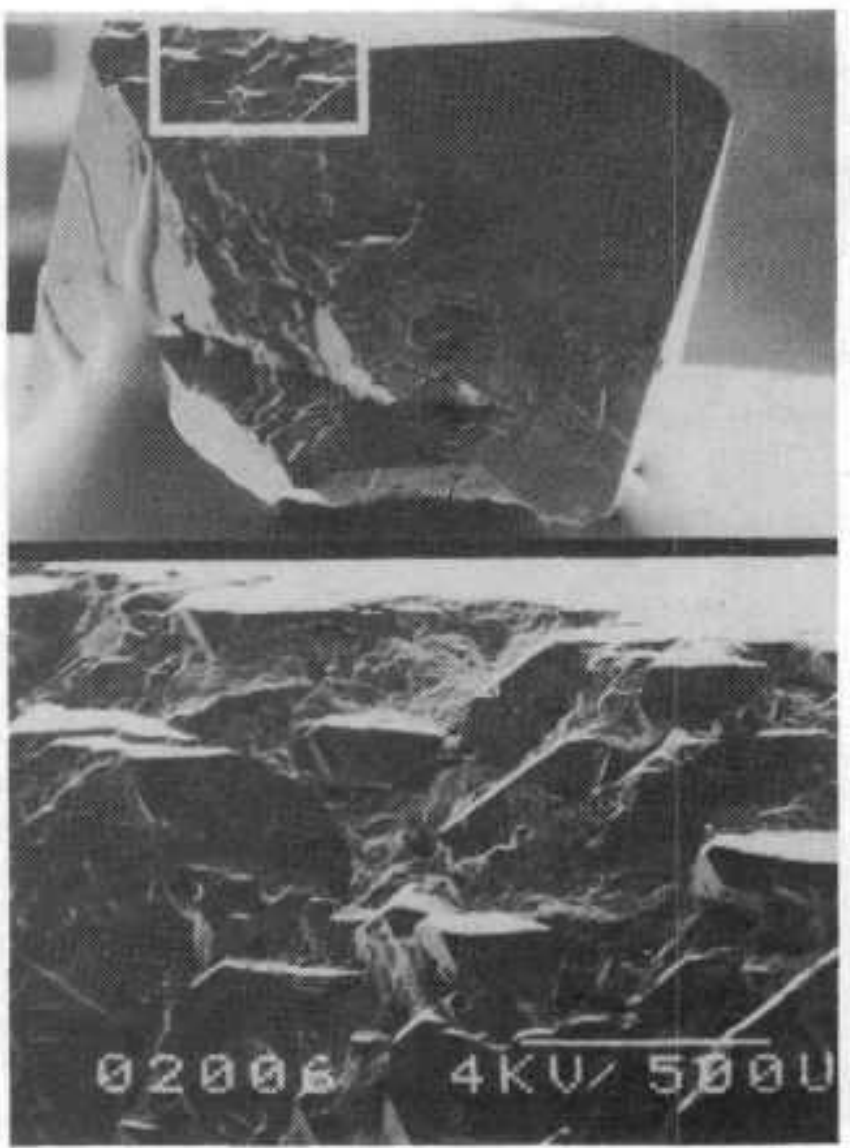

(a) Authigenic quartz crystal showing etching (upper photograph) and microcrystalline quartz overgrowths in the etched portion (lower photograph). (Scale bar $=500 \mu \mathrm{m}$ )

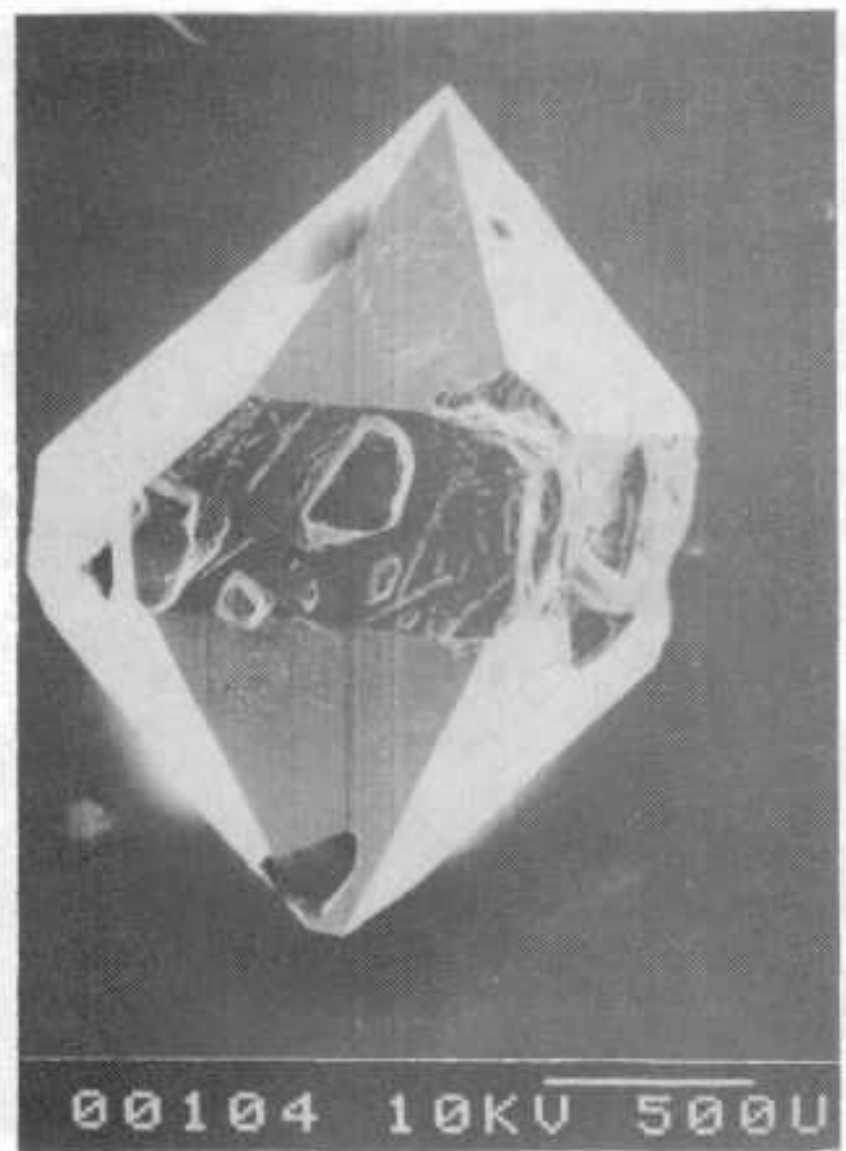

(b) Large authigenic quartz crystal from argillaceous WIPP salt showing well-developed etch features. (Scale bar= $500 \mu \mathrm{m}$ )

Figure 7. Scanning electron micrographs of authigenic quartz from argillaceous halite taken from the facility horizon 


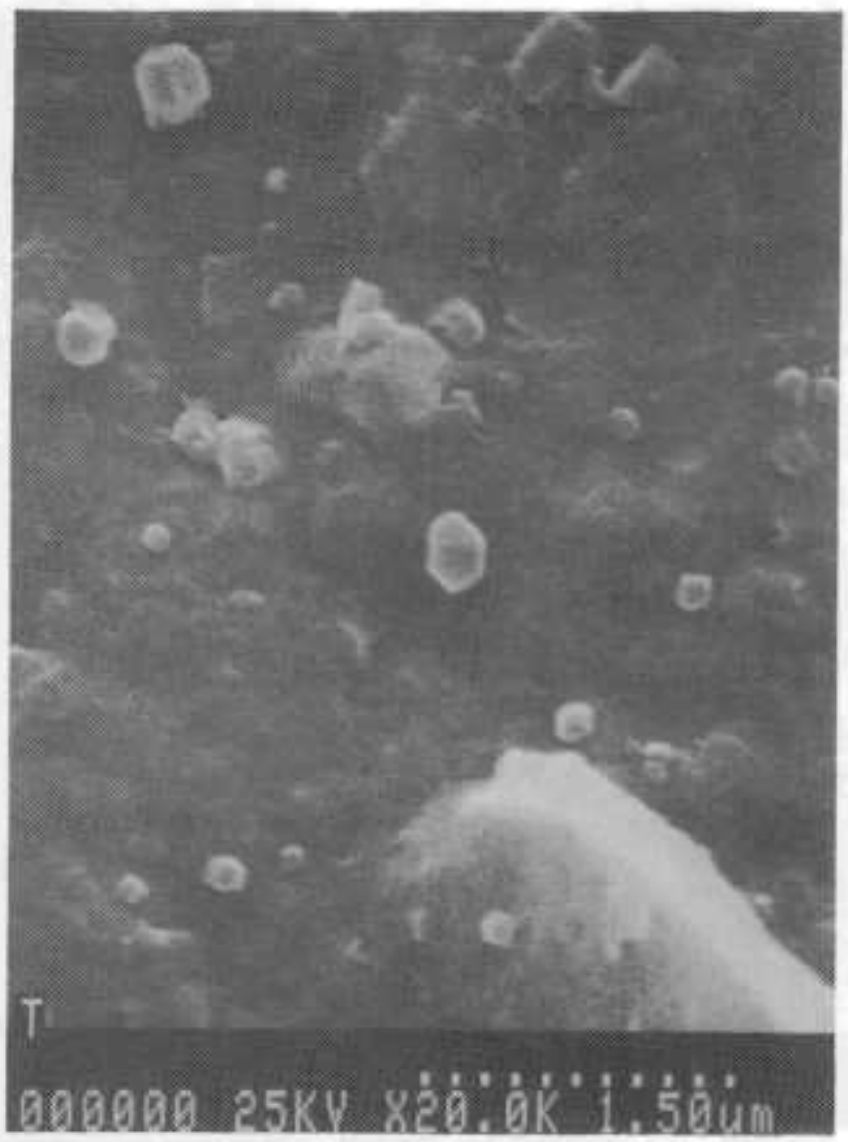

(a) Authigenic crystals of magnesite in clay (predominantly illitic) from WIPP salt. (Background, consisting of authigenic $\mathrm{Mg}$-rich clays, is largely amorphous, although occasional euhedral crystals are observed (arrow). Scale bar = $1.5 \mu \mathrm{m})$

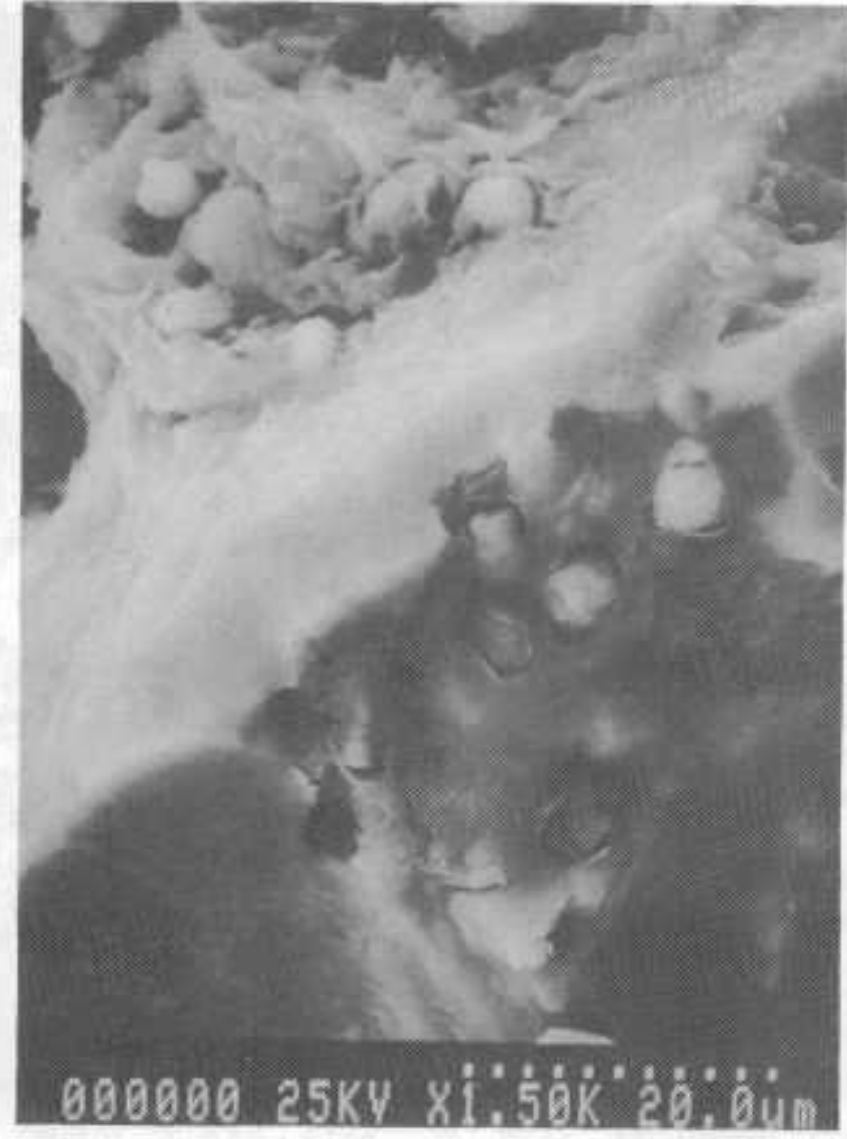

(b) Authigenic magnesite crystals growing in pits of surface of authigenic quartz crystal, suggesting that magnesite precipitation occurred after, or perhaps in conjunction with, corrosion of the quartz. (Scale bar $=20 \mu \mathrm{m}$ )

Figure 8. Scanning electron micrographs of authigenic magnesite found in argillaceous halite from the facility horizon 

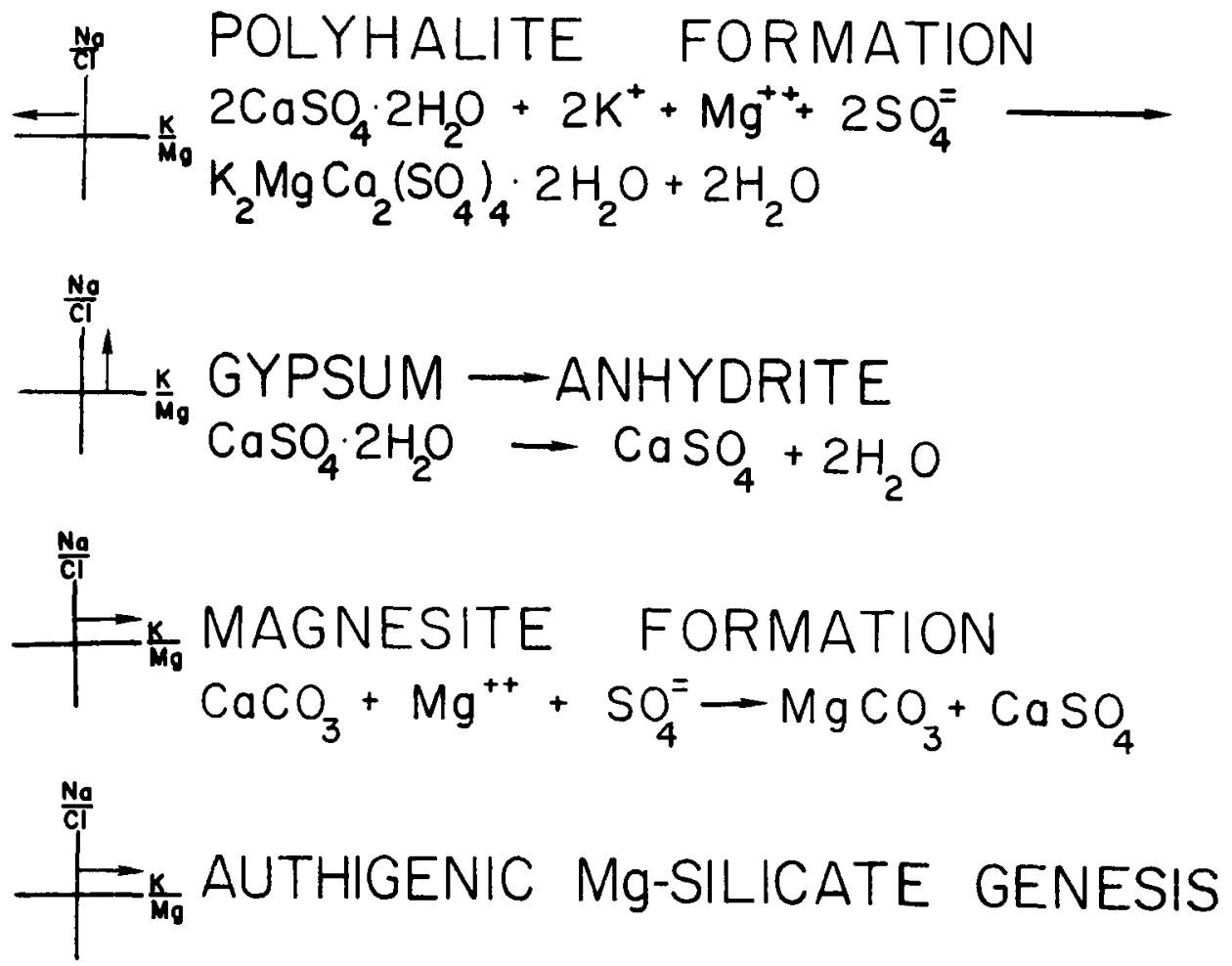

WIPP BRINES

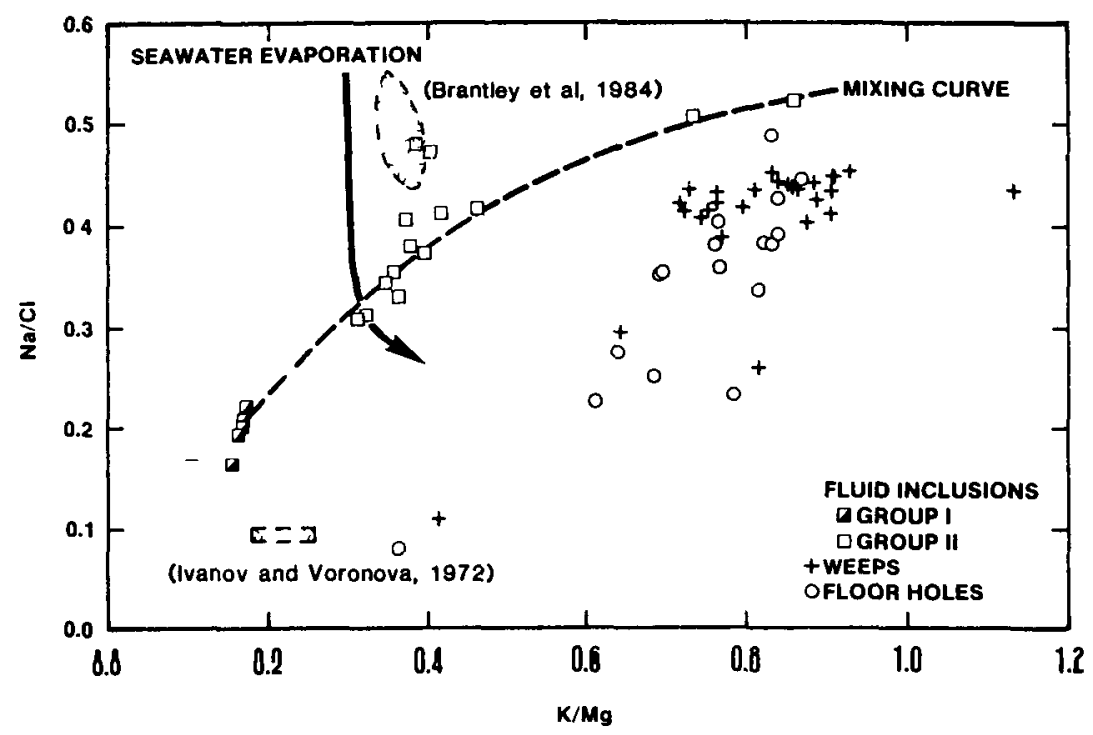

Figure 9. Summary of changes in fluid composition and accompanying mineralogical reactions 


\section{Technical Conclusions}

Several fundamental conclusions may be drawn from this work. First, the brines examined in this study contain significant amounts of dissolved $\mathrm{SO}_{4}^{2}$, $\mathrm{K}^{1}, \mathrm{Ca}^{2}$, and $\mathrm{Mg}^{2+}$ in addition to $\mathrm{Na}^{+}$and $\mathrm{Cl}$. Secondly, the inclusions that we analyzed are not uniform in composition but may be segregated into two distinct groups (Figures 1 and 9) which in turn are distinct from weeps and hole-filling solutions in the mine workings. The apparent control of fluid inclusion compositions by formation of secondary polyhalite and magnesite near the stratigraphic horizon containing the inclusion analyses presented here indicates vertical fluid movement of the order of tens of feet, at most. Furthermore, our evidence suggests that this fluid movement occurred soon after deposition. Silicate diagenesis, resulting in solutions depleted in magnesium relative to potassium and magnesium-rich solid phases, is also interpreted here as having occurred relatively soon after deposition. Thus this segregation of fluid compositions preserved a record of diagenetic processes that principally occurred before the close of the Paleozoic. This, and the fact that even weep samples show considerable variability, argue strongly against any sort of an interconnected hydrologic system at this stratigraphic level during the last hundred million years. Of broader interest is the fact that apparently it will be difficult to generalize regarding the composition of Paleozoic seawater from fluid inclusions in these evaporites because of the strong diagenetic overprint.

Finally, this study is preliminary, and much work remains to be done before fluid inclusions from the WIPP facility horizon will be fully characterized. These inclusions are atypical in size and may also have atypical compositions. Further laser Raman sulfate analyses may resolve this matter. Also, the distribution of inclusions seemingly is heterogeneous and needs to be mapped throughout the WIPP site and related to the recrystallization of the salt in which they are found. Another phenomenon not yet adequately explained is the behavior of fluid inclusions during migration along temperature gradients and during simultaneous mineral reactions. Finally, there are the more mundane analytic questions of (1) establishing a better statistical basis for predicting the overall range of compositions to be encountered; (2) obtaining more $\mathrm{SO}_{4}^{2}$ and perhaps $\mathrm{HCO}_{3}^{-}$analyses to supplement the $\mathrm{Cl}^{-}$values already available; (3) identifying the gas (or gases) present in the bubbles; and (4) analyzing the halite containing the inclusions to see if trace elements in the solid reflect variations in fluid composition.

\section{Programmatic Applications}

The brine compositions discussed in this report bear on several questions related to the emplacement of nuclear waste in a repository located in halite at a depth of $\sim 2150 \mathrm{ft}$ in the Salado Formation. Briefly, a discussion of the programmatic applications of this brine study is divided into three general areas: hydrology, brine migration, and materials testing. Although some tentative conclusions are advanced with regard to each topic, it cannot be stressed too strongly that they are based on a very small number of analyses. Thus the chief programmatic value of the work to date is to set forth a methodology for addressing such problems, assuming availability of sufficient resources, rather than to provide a body of "facts" able to withstand critical examination from the point of view of site suitability.

In the overall field of nuclear waste management, few questions are as important as quantifying the extent to which the groundwaters in a repository communicate with groundwaters in the adjacent units. Although present only in small amounts, groundwater clearly exists at the stratigraphic level of the WIPP repository. Further, the presence of the brine "weeps" indicates that, near an excavation, it is at least locally mobile. Lower down in the stratigraphic section, large brine pockets occur within fractured anhydrites of the Castile Formation (Register, 1981) and apparently are related to zones of intensely deformed halite. Because of the large size of such pockets, it is relevant to inquire whether the Castile brine occurrences are in any way related to the macroscopic brine occurrences observed in the WIPP facility. Therefore it is also a matter of significant interest to compare the chemical compositions of the Castile brines to those obtained from the brines collected from the WIPP facility, within the Salado Formation (as reported here). In fact, the compositional diversity that we describe herein apparently indicates that reservoirs of substantially different compositions located in close proximity to each other (e.g., within tens of feet) have failed to homogenize over periods of time far longer than that required for the isolation of nuclear waste. Nor do any of these compositions bear much resemblance to those found either above or below the Salado (Table 5 and Figure 10), in the Rustler and Castile Formations, respectively. Thus, the geochemistry of the system seems to preclude the existence of an interconnected hydrologic network effective on any time scale shorter than that required for the low-temperature silicate diagenesis, presumably thousands of years. 
The matter of brine migration is related to hydrology, but is distinct in that the focus is on the influence of the repository on fluid distribution. Two points may be made in regard to this subject. First, prior to this study it was thought that the weeps represented fluid inclusion mobilization by localized relief of the stress field in the halite adjacent to the open mine workings. Unless future analytic work yields a population of fluid inclusions of substantially different composition from those discussed here, this explanation of the origin of the weeps seems unlikely. Instead, it seems probable that the fluids giving rise to the weeps are intergranular and hence may migrate by mechanisms other than those thought to affect fluid inclusions (or the same mechansims but to different degrees). Second, this suggests the importance of investigating various migration phenomena. In the ongoing field tests at the WIPP, much effort and expense has been devoted to making large-scale measurements of brine migration in salt adjacent to experimental waste canisters. McTigue (1984) has developed a predictive model for brine migration for the simulated defense high-level waste experiments of Molecke (1984) based on the porothermoelastic behavior of salt around a heated borehole. Unless it is known what type of fluid is migrating as well as the migration mechanism(s), it seems likely that the results from such experiments may either be uninterpretable, or interpreted incorrectly. Since the fluids are compositionally distinct, though, this matter may be resolved if the salt deposits formed on the heater hole walls are collected and analyzed. Further, since different fluids may migrate to the heater over time, some thought should be given to the order in which various mineral components appear in these encrustations.

Finally, an examination of brine compositions bears directly on the matter of materials testing in general and on backfill performance specifically. Again, interpretation of the results from such testing is predicated on an accurate assessment of the fluid composition in which canister corrosion and alteration of backfill materials may take place. Of practical importance is the degree to which the brine analyses presented here resemble the reference brines formulated for environmental testing pertinent to WIPP. In some respects, the synthetic Brine A (Molecke, 1983, Table 5 and Figure 10) appears to be a reasonable match. At elevated temperatures several brinebentonite interactions can occur, depending on the chemical nature of the brine involved (Krumhansl, 1984; see also Figure 6). Brine A in fact contains sufficient magnesium and potassium to test the relative importance and consequences of formation of different clay mineral types. The formation of mixed- layer illite-smectite clays consumes $\mathrm{K}^{+}$and may degrade performance of backfill material around the waste canisters (Krumhansl, 1984). Alternatively, trioctahedral magnesium-rich smectite clays effect a drop in magnesium concentration in coexisting fluids and a lowering of the $\mathrm{pH}$ in the brine. The case for the general application of any one standard synthetic brine to radionuclide migration studies is ambiguous and requires more work.

Other aspects of the bentonite-brine problem relate to low-temperature backfill performance, and are less easily dealt with. The rheological properties of a bentonite backfill depend on the nature of the exchangeable cation on the clay. For example, the exchange of $\mathrm{Ca}$ or $\mathrm{Mg}$ for $\mathrm{Na}$ may significantly alter its swelling and plasticity. With regard to predicting farfield radionuclide migration, it is also necessary to make measurements in fluids that will reasonably approximate the compositions of those actually encountered in the WIPP. As an example, both Brines A and $B$ are much depleted in sulfate relative to those found in the field. Increasing the sulfate concentration from 3.5 to $25 \mathrm{ppt}$ increases the solubility of the actinide americium. This occurs because in the reference brines, sulfate complexes comprise $<5$ of the americium in solution, whereas in the field those complexes would account for $\sim 35 \%$ of the dissolved americium. Of this $35 \%$, about a third exists as anionic $\mathrm{Am}\left(\mathrm{SO}_{4}\right)_{2}^{-}$, which presumably would not sorb nearly as well as the cationic $\mathrm{AmCl}_{2}^{+}$and $\mathrm{AmCl}^{2+}$ that would predominate in Brines $\mathrm{A}$ or $\mathrm{B}$.

\section{Table 5. Summary of brine data (in ppt)}

\begin{tabular}{lccccccc} 
& $\mathrm{Ca}$ & $\mathrm{Mg}$ & $\mathrm{K}$ & $\mathrm{Na}$ & $\mathrm{Cl}$ & $\mathrm{Br}$ & $\mathrm{SO}_{4}$ \\
\hline Group I & 0.23 & 42.8 & 7.2 & 32.3 & 165 & 2.8 & 18.4 \\
Group II & 0.39 & 23.6 & 9.8 & 67.8 & 170.3 & 1.27 & 21.8 \\
Floor smpls. & 0.28 & 20.7 & 13.06 & 57.7 & 166.6 & 1.4 & 17.7 \\
Weeps $^{*}$ & 0.32 & 21.3 & 17.0 & 73.9 & 181.0 & 0.98 & 17.8 \\
Salado $^{+}$ & 0.61 & 45.5 & 29.8 & 34.8 & 204.1 & 0.38 & 2.8 \\
Rustler $^{\dagger}$ & 0.74 & 0.25 & 0.15 & 11.5 & 7.83 & - & 3.01 \\
Castile $^{\dagger}$ & 0.24 & 0.64 & 2.13 & 65.8 & 103.8 & 0.1 & 9.3 \\
Brine A $^{\dagger}$ & 0.5 & 29.2 & 25.0 & 35.0 & 158.3 & 0.3 & 2.9 \\
Brine B $^{\ddagger}$ & 0.75 & 0.008 & 0.01 & 95.8 & 145.8 & 0.3 & 2.9
\end{tabular}

*Weep data for $\mathrm{Ca}, \mathrm{Mg}, \mathrm{K}, \mathrm{Na}$, and $\mathrm{Cl}$ include averages of only one set of samples (those in Table 2). $\mathrm{Br}$ and $\mathrm{SO}_{4}$ data are taken from a preliminary set of samples that were analyzed for $\mathrm{Br}$ and $\mathrm{SO}_{4}$ but are not reported here because of apparent contamination with halite.

$\dagger$ From Lambert (1978)

$\ddagger$ From Molecke (1983) 


\section{WIPP BRINE COMPOSITIONS}

$\begin{array}{ll}\text { INCLUSIONS } & =\mathbf{I} \\ \text { HOLES } & =H \\ \text { WEEPS } & =H\end{array}$

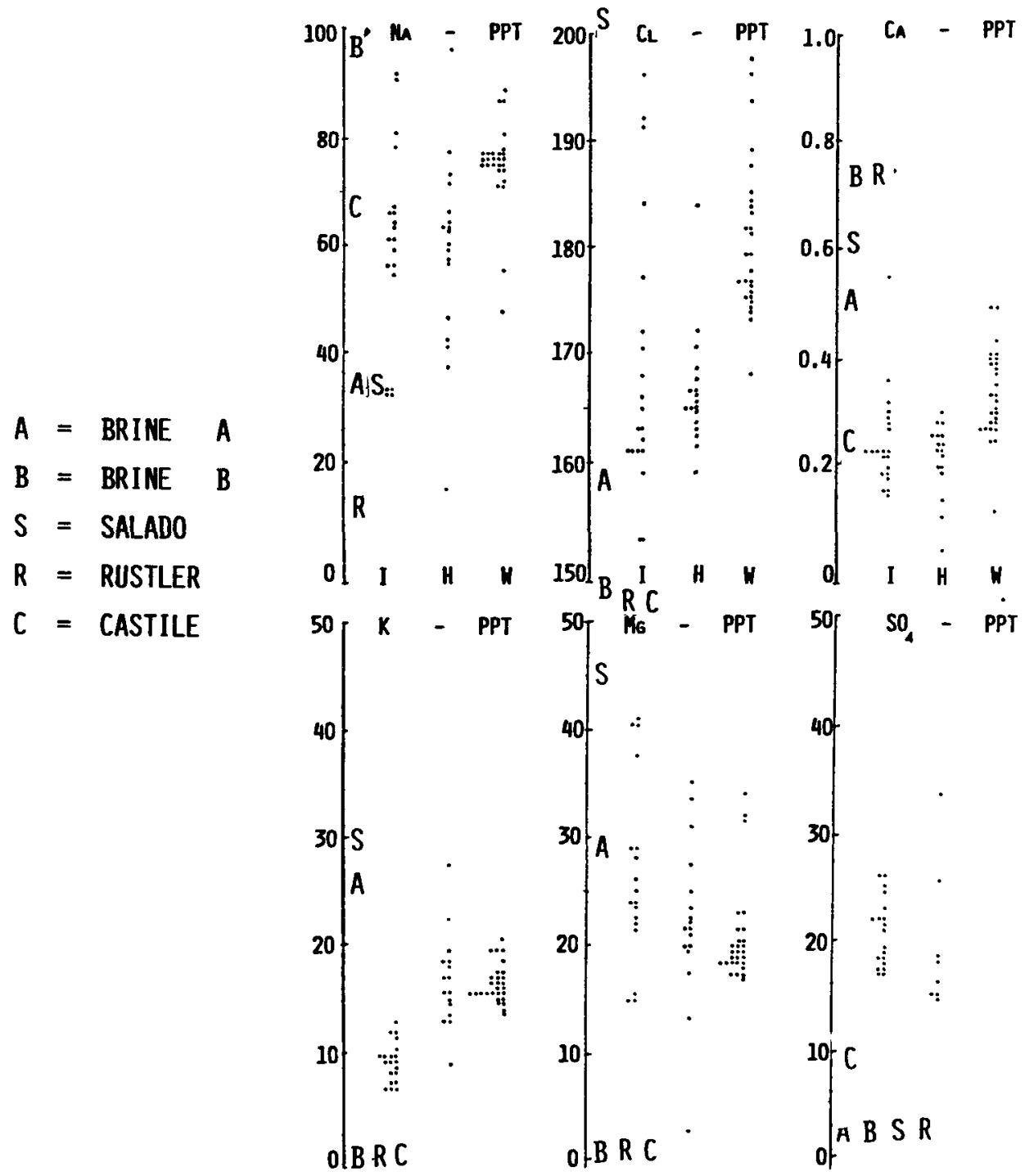

Figure 10. Summary figure of brine compositions (Data for the Rustler, Salado, and Castile brines have been taken from Lambert (1978) and represent averaged values of those formation waters.) 
With regard to the general topic of materials testing, then, the following generalizations can be made as a result of this study. It is probable that a variety of fluids may come in contact with the components under consideration (e.g., backfill, waste, or canister). Whether these variations will influence the course of interactions around a waste canister cannot be reliably determined in advance; otherwise there would be little justification in experimentally evaluating their performance. Consequently, any program in materials testing must employ a wide range of brine compositions rather than one or two reference brines as has been the practice in the past. We note here that the focus of this paper is only the compositions of, and possible consequences related to, Salado brines. The work presented here presupposes an environment that is completely isolated; e.g., by successful plugging and sealing. However, other scenarios have in fact taken into account influxes of brines from other sources, in much larger amounts and of different compositions than those discussed here.

\section{References}

Berner, R., Princtples of Chemical Sedımentology (New York: McGraw-Hill, 1971).

Bodıne, Jr., M W., Clay-Mineral Assemblages from Drill Core of Ochoan Evaporttes, Eddy County, New Mexico Bureau of Mines and Mineral Resources Circ. 159, pp 21-31 (1978).

Bodıne, Jr, M. W., and T. H. Fernalld, "EDTA Dissolution of Gypsum, Anhydrite, and $\mathrm{Ca}-\mathrm{Mg}$ Carbonates," J Sed Petrology, 434:1152-1156 (1973).

Brantley, S. L., D. A Crerar, N. E. Moller, and J. H. Weare, "Geochemistry of a Modern Marine Evaporite: Bocana de Virilla, Peru," J Sed Petrology, 542:447-462 (1984).

Brookins, D., "Polyhalite K-Ar Radiometric Ages from Southeastern New Mexico," Isochron West 29:29-31 (1980).

Cheeseman, R. J., "Geology and Oil/Potash Resources of Delaware Basin, Eddy and Lea Counties, New Mexico," in Geology and Mineral Deposits of Ochoan Rocks in Delaware Basin and Adjacent Areas, G. S. Austin, ed, New Mexico Bureau of Mines and Mineral Resources Circ. 159, pp 7-14 (1978).

Holser, W.T., "Chemistry of Brine Inclusions in Permian Salt from Hutchison, Kansas," in Symposium on Salt, J.L. Rau, ed, Northern Ohio Geological Society, pp 86-103 (1963).

Ivanov, A. A., and M. L. Voronova, Evaportte Formation (in Russian), Nedra, Moscow, 1972, in Sonnenfeld, P., Brınes and Evaporttes (Orlando, FL: Academic Press, Inc., 1984)
Knauth, L. Paul, Arizona State University (personal communication).

Krumhansl, J. L., Observations Regarding the Stablity of Bentonite Backfill in a High-Level Waste (HLW) Repository in Rock Salt, SAND83-1293 (Albuquerque, NM: Sandia National Laboratories, 1984).

Krumhansl, J. L., W. R. Sorenson, and C. L. Stein, Clay Mineral Diagenesis and Magnesium Sillcate Formation in Halıte from the WIPP Site, Southeastern New Mexico (ms in preparation) (Albuquerque, NM: Sandia National Laboratories, 1985).

Lambert, S. J., The Geochemistry of Delaware Basın Groundwater, New Mexico Bureau of Mines and Mineral Resources Circ. 159, pp 33-38 (1978).

Mc'Tigue, D. F., Sandia National Laboratories "Brine Flow to a Heated Borehole," internal memo to C. L. Stein, Sandia National Laboratories, August 13, 1984.

Merrill, R. M., The Analysıs of Anıons in Geologlcal Brınes Using Ion Chromatography, SAND84-2297 (Albuquerque, NM: Sandia National Laboratories, 1985).

Molecke, M. A., A Compartson of Brines Relevant to Nuclear Waste Experimentation, SAND83-0516 (Albuquerque, NM: Sandia National Laboratories, 1983).

Molecke, M. A., Test Plan Waste Package Performance Technology Experiments for Simulated DHLW, WPPDHLW-TE (Albuquerque, NM: Sandia National Laboratories, June 1984).

Register, J. K., Brine Pocket Occurrences in the Castlle Formation, Southeastern New Mexıco, TME 3080 (Albuqerque, NM: TSC/D'Appolonia Consulting Engineers, Inc. for Sandia National Laboratories, 1981).

Roedder, E., US Geological Survey (personal communication).

Stein, C. L., Halıte Mineralogy in the WIPP Facılity Stratıgraphic Horlzon, SAND85-0321 (Albuquerque, NM: Sandia National Laboratories, 1985a).

Stein, C. L., Prelıminary Report on Fluid Inclusions from Halites in the Castlle and Lower Salado Formations of the Delaware Basin, Southeastern New Mexıco, SAND83-0451 (Albuquerque, NM: Sandia National Laboratories, 1985b).

Tallant, D. R., K. L. Higgins, and C. L. Stein, "Raman Microscopy Through Transparent Materials," in Gooley, R., ed, Microbeam Analysus 1983 Proceedings of the 18th Annual Conference of the Microbeam Analysts Socıety, pp 297-300 (1983).

Usıglio, M. J., "Études Sur la Compositıon de l'eau de la Mediterranée et Sur L'exploitation des Sels Qu'elle Contient," Annales Chım Phys, 27(3):172-191 (1849).

US Department of Energy, Results of Site Validation Experiments, Vol. II, supporting documents 5 through 14. Technical Support Contract DE-AC04-78AL05346, TME 3177 (Albuquerque, NM: US DOE, 1983). 


.




\section{APPENDIX A}

\section{Common Evaporite Minerals and Their Formulas}

\begin{tabular}{ll}
\hline Mineral & Composition \\
\hline Halite & $\mathrm{NaCl}$ \\
Anhydrite & $\mathrm{CaSO}_{4}$ \\
Gypsum & $\mathrm{CaSO}_{4} \cdot 2 \mathrm{H}_{2} \mathrm{O}$ \\
Polyhalite & $\mathrm{K}_{2} \mathrm{MgCa}_{2}\left(\mathrm{SO}_{4}\right)_{4} \cdot 2 \mathrm{H}_{2} \mathrm{O}$ \\
Glauberite & $\left.\mathrm{Na}_{2} \mathrm{Ca}_{(} \mathrm{SO}_{4}\right)_{2}$ \\
Magnesite & $\mathrm{MgCO}_{3}$ \\
Calcite & $\mathrm{CaCO}_{3}$ \\
Dolomite & $\mathrm{CaMg}\left(\mathrm{CO}_{3}\right)_{2}$ \\
Quartz & $\mathrm{SiO}_{2}$ \\
\hline
\end{tabular}




\section{APPENDIX B \\ Potash Zone Mineralogy \\ (from Cheeseman, 1978)}

\begin{tabular}{ll}
\hline \hline Ore Minerals & Composition \\
\hline Sylvite & $\mathrm{KCl}$ \\
Langbeinite & $\mathrm{K}_{2} \mathrm{Mg}_{2}\left(\mathrm{SO}_{4}\right)_{3}$ \\
\hline
\end{tabular}

\begin{tabular}{ll}
\hline \hline & \\
Gangue Minerals & Composition \\
\hline Leonite & $\mathrm{K}_{2} \mathrm{Mg}\left(\mathrm{SO}_{4}\right)_{2} \cdot 4 \mathrm{H}_{2} \mathrm{O}$ \\
Kainite & $\mathrm{KMgClSO}_{4} \cdot 3 \mathrm{H}_{2} \mathrm{O}$ \\
Carnallite & $\mathrm{KMgCl}_{3} \cdot 6 \mathrm{H}_{2} \mathrm{O}$ \\
Kieserite & $\mathrm{MgSO}_{4} \cdot \mathrm{H}_{2} \mathrm{O}$ \\
Bloedite & $\mathrm{Na}_{2} \mathrm{Mg}_{4}\left(\mathrm{SO}_{4}\right)_{2} \cdot 4 \mathrm{H}_{2} \mathrm{O}$ \\
Polyhalite & $\mathrm{K}_{2} \mathrm{Ca}_{2} \mathrm{Mg}\left(\mathrm{SO}_{4}\right)_{4} \cdot 2 \mathrm{H}_{2} \mathrm{O}$ \\
Anhydrite & $\mathrm{CaSO}_{4}$ \\
Halite & $\mathrm{NaCl}$ \\
\hline
\end{tabular}




\section{DISTRIBUTION:}

US Department of Energy, Headquarters (2) Office of Nuclear Waste Management

Attn: A. Follett, Project Coordinator (WIPP) R. Stein

Washington, DC 20545

US Department of Energy (2)

Albuquerque Operations Office

Attn: G. C. Romatowski

D. G. Jackson, Dir, Public Affairs Div

PO Box 5400

Albuquerque, NM 87185

US Department of Energy (6)

Attn: W. R. Cooper Carlsbad WIPP Project Office (2)

PO Box 3090

A. Hunt, WPO (Carlsbad) (4)

Carlsbad, NM 88221

US Department of Energy

Carlsbad WIPP Project Office

Room 113, Federal Bldg

Carlsbad, NM 88220

US Department of Energy, NPO (2)

Office of Nuclear Waste Isolation

Attn: Jeff O. Neff

R. Wunderlich

505 King Ave

Columbus, $\mathrm{OH} 43201$

US Department of Energy

Richland Operations Office

Nuclear Fuel Cycle and Production Div

Attn: R. E. Gerton

PO Box 500

Richland, WA 99352

US Department of Energy

Research and Tech Support Div

Attn: D. E. Large

PO Box E

Oak Ridge, TN 37830

US Department of Energy (2)

Division of Waste Products

Attn: G. H. Daly

J. E. Dieckhoner

Mail Stop B-107

Washington, DC 20545
US Department of Energy (2)

Idaho Operations Office

Nuclear Fuel Cycle Div

Attn: R. M. Nelson

J. Whitsett

550 Second St

Idaho Falls, ID 83401

US Department of Energy (4)

Savannah River Operations Office

Waste Management Project Office

Attn: J. R. Covell

D. Fulmer

S. Cowan

W. J. Brumley

PO Box A

Aiken, SC 29801

US Nuclear Regulatory Commission (3)

Division of Waste Management

Attn: Michael Bell

Hubart Miller

Jacob Philip

Mail Stop 697SS

Washington, DC 20555

US Nuclear Regulatory Commission

HLW Licensing Branch, Materials Section

Attn: F. R. Cook

MS 905 SS

Washington, DC 20555

Battelle Memorial Inst (17)

Project Management Div

Attn: W. Carbiener, General Manager (3)

S. Basham

D. E. Clark

S. Goldsmith

J. E. Hanley

P. Hoffman

H. R. Hume

H. N. Kalia

J. Kircher

S. Matthews

D. Moak

J. Moody

G. Raines

J. Treadwell

ONWI Library

505 King Ave

Columbus, OH 43201 
DISTRIBUTION (continued):

Battelle Pacific Northwest, Labs (4)

Attn: D. J. Bradley

J. Relyea

R. P. Turcotte

R. E. Westerman

Battelle Blvd

Richland, WA 99352

Westinghouse Electric Corp (9)

Attn: P. Miskimin

V. Likar

L. Cole

V. DeJong

R. Gehrman

J. Johnson

J. W. Sadler

J. E. Stumbaugh

Library

PO Box 2078

Carlsbad, NM 88221

Bechtel, Inc (5)

Attn: E. Weber

H. Taylor

P. Frobenius

D. L. Wu

W. T. Li

45-11-B34

PO Box 3965

San Francisco, CA 94119

Oak Ridge National Lab (4)

Attn: R. E. Blanko

E. Bondietti

C. Claiborne

G. H. Jenks

PO Box Y

Oak Ridge, TN 37830

Oak Ridge National Lab

Attn: John O. Blomeke

PO Box X

Oak Ridge, TN 37830

US Geological Survey

Water Resources Div

Attn: John D. Bredehoeft, Western Region Hydrologist

345 Middlefield Rd

Menlo Park, CA 94025
Dr. Karl P. Cohen

928 N California Ave

Palo Alto, CA 94303

Stanford University

National Acad. of Sci., WIPP Panel

Dept. of Geology

Attn: Konrad B. Krauskopf, Chairman

Palo Alto, CA 94305

Vanderbilt University

Dept. of Environmental and

Water Resources Engineering

Attn: Frank L. Parker, Vice Chm.

Nashville, TN 37235

University of Florida

Department of Material Sciences and Engineering

Attn: Fred M. Ernsberger, Adjunct Professor

Gainesville, FL 32611

Johns Hopkins University

Department of Earth Sciences

Attn: Hans P. Eugster

Baltimore, MD 21218

University of New Mexico

Department of Geology

Attn: Rodney C. Ewing

Albuquerque, NM 87131

University of Minnesota

Department of Geological Sciences

Attn: Charles Fairhurst

Minneapolis, MN 55455

University of Texas at Austin

Department of Geological Sciences

Attn: William R. Muehlberger

Austin, TX 78712

D'Arcy A. Shock

233 Virginia

Ponca City, OK 74601

National Academy of Sciences

Committee on Radioactive Waste Management

Attn: John T. Holloway, Senior Staff Officer

2101 Constitution Ave, NW

Washington, DC 20418 
DISTRIBUTION (continued):

Hobbs Public Library

Attn: Marcia Lewis, Librarian

509 N. Ship St

Hobbs, NM 88248

NM Inst of Mining/Tech

Martin Speere Memorial Library

Campus St

Socorro, NM 87810

New Mexico State Library

Attn: Ingrid Vollenhofer

PO Box 1629

Santa Fe, NM 87503

University of New Mexico

Zimmerman Library

Attn: Zanier Vivian

Albuquerque, NM 87131

WIPP Public Reading Room

Attn: Gwynn Schreiner

Atomic Museum, Kirtland AFB, East

Albuquerque, NM 87185

WIPP Public Reading Room

Carlsbad Municipal Library

Attn: Lee Hubbard, Head Librarian

$101 \mathrm{~S}$ Hallagueno St

Carlsbad, NM 88220

Thomas Brannigan Library

Attn: Don Dresp, Head Librarian

106 W Hadley St

Las Cruces, NM 88001

Roswell Public Library

Attn: Nancy Langston

301 N Pennsylvania Ave

Roswell, NM 88201

State of New Mexico (2)

Environmental Evaluation Group

Attn: Robert H. Neill, Dir

PO Box 968

Santa Fe, NM 87503

NM Department of Energy and Minerals (2)

Attn: Larry Kehoe, Secretary Kasey LaPlante, Librarian

PO Box 2770

Santa Fe, NM 87501
Argonne National Lab (5)

Attn: S. Fried

A. M. Friedman

D. Hambeley

N. Meldgin

M. Steindler

9700 S Cass Ave

Argonne, IL 60439

Brookhaven National Lab (2)

Attn: P. Colombo, Dept of Applied Sciences Cal Brewster, Bldg 830

Upton, NY 11973

Brookhaven National Lab

Associated Universities, Inc

Attn: Paul W. Levy, Senior Scientist

Upton, NY 11973

IT Corp (4)

Attn: P. Kelsall

R. McKinney

A. Moss

D. Shukla

Suite 306

2350 Alamo, SE

Albuquerque, NM 87106

E. I. Dupont de Nemours Co (4)

Attn: N. Bibler

E. J. Hennelly

M. J. Plodinec

G. G. Wicks

Savannah River Lab

Aiken, SC 29801

E. I. Dupont de Nemours Co

Attn: R. Baxter

Savannah River Plant

Aiken, SC 29801

Oak Ridge National Laboratory, Bldg. 2001

Ecological Sciences Information Center

Attn: C. S. Fore

PO Box X

Oak Ridge, TN 37830

Texas A\&M University

Center of Tectonophysics

Attn: John Handin

College Station, TX 77840 
DISTRIBUTION (continued):

J. F. T. Agapito Assoc, Inc

Attn: Christopher St. John

715 Horizon Dr, Suite 340

Grand Junction, CO 81501

Science Applications, Inc

Attn: D. E. Maxwell

2450 Washington Ave, Suite 120

San Leandro, CA 94577

Los Alamos National Lab

Attn: B. Erdal, CNC-11

PO Box 1663

Los Alamos, NM 87545

Rockwell International (3)

Atomics International Div

Attn: M. J. Smith

W. W. Schultz

P. Salter

Rockwell Hanford Operations

PO Box 800

Richland, WA 99352

US Department of Interior

Geological Survey

Attn: E. Roedder

959 National Center

Reston, VA 22092

Serata Geomechanics

Attn: Dr. Shosei Serata

4124 Lakeside Dr

Richmond, CA 94806-1941

Systems, Science, and Software (2)

Attn: P. Lagus

E. Peterson

Box 1620

La Jolla, CA 92038

Titanium Metals Corp of America

Henderson Technical Lab

Attn: R. W. Schulz

PO Box 2128

Henderson, NV 89015
US Army Engineers (8)

Waterways Experiment Station

Attn: D. Ainsworth

J. Armstrong

J. Boa

A. Buck

K. Mather

C. Pace

L. Wakeley

D. Walley

PO Box 631

Vicksburg, MS 39180

University of Arizona

Department of Mining

and Geological Engineering

Attn: J. J. K. Daemen

Tucson, AZ 85721

University of New Mexico

Geology Department

Attn: D. G. Brookins

Albuquerque, NM 87131

Cornell University

Department of Physics

Attn: Dr. R. O. Pohl

Clark Hall

Ithaca, NY 14853

Cornell University

Department of Mechanical

and Aerospace Engineering

Attn: Dr. Paul R. Dawson

254 Upson Hall

Ithaca, NY 14853

University of Minnesota

Department of Energy

and Materials Science

Attn: R. Oriani

151 Amundson Hall

421 Washington Ave, SE

Minneapolis, MN 55455

The Pennsylvania State University (2)

Materials Research Lab

Attn: Della Roy

Rustum Roy

University Park, PA 16802 
DISTRIBUTION (continued):

Princeton University

Dept of Civil Engineering

Attn: George Pinder

Princeton, NJ 08540

RE/SPEC, Inc (4)

Attn: P. Gnirk

T. Pfeifle

R. Stickney

L. Van Sambeek

PO Box 725

Rapid City, SD 57701

RE/SPEC, Inc (2)

Attn: S. W. Key

D. B. Blankenship

PO Box 14984

Albuquerque, NM 87191

Rockwell International (2)

Rocky Flats Plant

Attn: W. S. Bennett

C. E. Wickland

Golden, CO 80401

US Geological Survey

Special Projects

Attn: R. Snyder

MS954, Box 25046

Denver Federal Center

Denver, CO 80255

US Geological Survey

PO Box 26659

Albuquerque, NM 87125

Woodward-Clyde Consultants (2)

Library Western Region

Attn: Anne T. Harrigan, Librarian

Charles Taylor

3 Embarcadero Center, Suite 700

San Francisco, CA 94111

Institut fur Tieflagerung (3)

Attn: K. Kuhn

N. Jockwer

H. Gies

Theodor-Heuss-Strasse 4

D-3300 Braunschweig

FEDERAL REPUBLIC OF GERMANY
Bundesanstalt fur Geowissenschaften und Rohstoffe Attn: Michael Langer

Postfach 510153

3000 Hannover 51

FEDERAL REPUBLIC OF GERMANY

Hahn-Mietner-Institut fur Kernforschung

Attn: Klaus Eckart Maass

Glienicker Strasse 100

1000 Berlin 39

FEDERAL REPUBLIC OF GERMANY

Bundesministerium fur Forschung und Technologie Attn: Rolf-Peter Randl

Postfach 200706

5300 Bonn 2

FEDERAL REPUBLIC OF GERMANY

Physikalisch-Technische Bundesanstalt

Attn: Helmut Rothemeyer

Bundesanstalt 100

3300 Braunschweig

FEDERAL REPUBLIC OF GERMANY

Kernforschung Karlsruhe (3)

Attn: R. Koster

Reinhard Kraemer

K. D. Closs

Postfach 3640

7500 Karlsruhe

FEDERAL REPUBLIC OF GERMANY

Underground Storage of Radioactive Waste

Experimental Programs

Attn: Tuen Deboer, Manager

PO Box 1

1755 ZG Petten

THE NETHERLANDS

Svensk Karnbransleforsorjning AB

Project KBS

Karnbranslesakerhet

Attn: Fred Karlsson

Box 5864

10248 Stockholm

SWEDEN 
DISTRIBUTION (continued):

\begin{tabular}{|c|c|c|c|}
\hline \multicolumn{2}{|c|}{ Ontario Hydro Research Lab } & 6331 & S. J. Lambert \\
\hline \multicolumn{2}{|c|}{ Attn: Dr. D. K. Mukerjee } & 6331 & W. B. Miller \\
\hline \multicolumn{2}{|c|}{800 Kipling Ave } & 6331 & K. L. Robinson \\
\hline \multicolumn{2}{|c|}{ Toronto, Ontario } & 6331 & S. E. Shaffer \\
\hline \multicolumn{2}{|c|}{ MBZ 554} & 6331 & C. L. Stein (11) \\
\hline \multirow{2}{*}{\multicolumn{2}{|c|}{ CANADA }} & 6332 & A. J. Arguello \\
\hline & & 6332 & R. Beraun \\
\hline 1500 & W. Herrmann & 6332 & C. L. Christensen \\
\hline 1510 & J. W. Nunziato & 6332 & D. M. Ellett \\
\hline 1520 & D. J. McCloskey & 6332 & R. V. Matalucci \\
\hline 1521 & R. D. Krieg & 6332 & M. A. Molecke \\
\hline 1521 & H. S. Morgan & 6332 & D. E. Munson \\
\hline 1530 & L. W. Davison & 6332 & E. J. Nowak \\
\hline 1540 & W. C. Luth & 6332 & J. C. Stormont \\
\hline 1542 & B. M. Butcher & 6332 & T. M. Torres \\
\hline 1542 & D. J. Holcomb & 6332 & L. D. Tyler (10) \\
\hline 1542 & L. W. Teufel & 6332 & F. G. Yost \\
\hline 1542 & W. R. Wawersik & 6332 & Sandia WIPP Central Files (HLW) (2) \\
\hline 1543 & J. L. Krumhansl (11) & 6334 & L. H. Brush \\
\hline 1543 & W. H. Casey & 7100 & C. D. Broyles \\
\hline 1543 & T. M. Gerlach & 7110 & J. D. Plimpton \\
\hline 1820 & R. E. Whan & 7112 & C. R. Mehl \\
\hline 1830 & M. J. Davis & 7112 & G. H. Miller \\
\hline 1832 & W. B. Jones & 7116 & E. S. Ames \\
\hline 1832 & J. W. Munford & 7116 & C. W. Cook \\
\hline 1832 & J. A. Van Den Avyle & 7116 & S. R. Dolce \\
\hline 1833 & G. A. Knorovsky & 7120 & M. J. Navratil \\
\hline 1840 & R. J. Eagan & 7125 & J. T. McIlmoyle \\
\hline 1841 & R. B. Diegle & 7125 & G. L. Ogle \\
\hline 1841 & N. R. Sorensen & 7130 & J. D. Kennedy \\
\hline 3310 & W. D. Burnett & 7133 & C. W. Gulick \\
\hline 6000 & E. H. Beckner & 7133 & R. D. Statler \\
\hline 6253 & D. A. Northrop & 7135 & P. D. Seward \\
\hline 6253 & A. R. Sattler & 8310 & R. W. Rohde \\
\hline 6257 & R. R. Beasley & 8314 & N. R. Moody \\
\hline 6257 & J. K. Linn & 8314 & M. W. Perra \\
\hline 6258 & B. J. Thorne & 8314 & S. L. Robinson \\
\hline 6300 & R. W. Lynch & 8315 & D. H. Doughty \\
\hline 6310 & T. O. Hunter & 8315 & L. A. West \\
\hline 6311 & L. W. Scully & 8430 & L. D. Bertholf \\
\hline 6312 & F. W. Bingham & 8024 & P. W. Dean \\
\hline 6314 & J. R. Tillerson & 3141 & S. A. Landenberger (5) \\
\hline 6330 & W. D. Weart & 3151 & W. L. Garner (3) \\
\hline 6331 & A. R. Lappin & $3154-3$ & C. H. Dalin (28) \\
\hline 6331 & G. E. Barr & & For DOE/OSTI (Unlimited Release) \\
\hline
\end{tabular}

